\title{
Numerical analysis of the chemical kinetic mechanisms of ozone depletion and halogen release in the polar troposphere
}

\author{
L. Cao ${ }^{1}$, H. Sihler ${ }^{2,3}$, U. Platt ${ }^{2}$, and E. Gutheil ${ }^{1}$ \\ ${ }^{1}$ Interdisciplinary Center for Scientific Computing, University of Heidelberg, Heidelberg, Germany \\ ${ }^{2}$ Institute for Environmental Physics, University of Heidelberg, Heidelberg, Germany \\ ${ }^{3}$ Max Planck Institute for Chemistry, Mainz, Germany
}

Correspondence to: L. Cao (le.cao@iwr.uni-heidelberg.de)

Received: 9 July 2013 - Published in Atmos. Chem. Phys. Discuss.: 13 September 2013

Revised: 24 January 2014 - Accepted: 1 March 2014 - Published: 15 April 2014

\begin{abstract}
The role of halogen species (e.g., $\mathrm{Br}, \mathrm{Cl}$ ) in the troposphere of polar regions has been investigated since the discovery of their importance for boundary layer ozone destruction in the polar spring about 25 years ago. Halogen species take part in an auto-catalytic chemical reaction cycle, which releases $\mathrm{Br}_{2}$ and $\mathrm{BrCl}$ from the sea salt aerosols, fresh sea ice or snowpack, leading to ozone depletion. In this study, three different chemical reaction schemes are investigated: a bromine-only reaction scheme, which then is subsequently extended to include nitrogen-containing compounds and chlorine species and corresponding chemical reactions. The importance of specific reactions and their rate constants is identified by a sensitivity analysis.

The heterogeneous reaction rates are parameterized by considering the aerodynamic resistance, a reactive surface ratio, $\beta$, i.e., the ratio of reactive surface area to total ground surface area, and the boundary layer height, $L_{\text {mix }}$. It is found that for $\beta=1$, a substantial ozone decrease occurs after five days and ozone depletion lasts for $40 \mathrm{~h}$ for $L_{\text {mix }}=200 \mathrm{~m}$. For about $\beta \geq 20$, the time required for major ozone depletion $\left(\left[\mathrm{O}_{3}\right]<4 \mathrm{ppb}\right)$ to occur becomes independent of the height of the boundary layer, and for $\beta=100$ it approaches two days, $28 \mathrm{~h}$ of which are attributable to the induction and $20 \mathrm{~h}$ to the depletion time.

In polar regions, a small amount of $\mathrm{NO}_{\mathrm{x}}$ may exist, which stems from nitrate contained in the snow, and may have a strong impact on the ozone depletion. Therefore, the role of nitrogen-containing species on the ozone depletion rate is studied. The results show that the $\mathrm{NO}_{\mathrm{x}}$ concentrations are influenced by different chemical reactions over different time periods. During ozone depletion, the reaction cycle involv-
\end{abstract}

ing the $\mathrm{BrONO}_{2}$ hydrolysis is dominant. A critical value of 0.0004 of the uptake coefficient of the $\mathrm{BrONO}_{2}$ hydrolysis reaction at the aerosol and saline surfaces is identified, beyond which the existence of $\mathrm{NO}_{\mathrm{x}}$ species accelerates the ozone depletion event, whereas for lower values, deceleration occurs.

\section{Introduction, state of the art, and objectives}

Since the 1980s, it has been reported that during polar spring, the amount of ozone in the atmospheric polar boundary layer may decrease from the background value of tens of parts per billion (ppb) to less than $1 \mathrm{ppb}$ or even under the detection limit (Oltmans, 1981; Barrie et al., 1988, 1989; Oltmans et al., 1989; Helmig et al., 2007, 2012). The observed depletion time varies from several hours to days. During the ozone depletion event, a sudden release of halogen species $\left(X, X_{2}\right.$, $\mathrm{XY}, \mathrm{XO}, \mathrm{HOX}$, where $\mathrm{X}$ and $\mathrm{Y}$ denote halogen atoms such as $\mathrm{Br}$ and $\mathrm{Cl}$ ) has been detected in both the Arctic and Antarctic (Hausmann and Platt, 1994; Kreher et al., 1997; Tuckermann et al., 1997; Hönninger and Platt, 2002; Frieß et al., 2004; Wagner et al., 2007; Liao et al., 2012; Stephens et al., 2012).

Halogen species are involved in an autocatalytic chemical cycle, leading to ozone depletion (Wayne et al., 1995; Platt and Janssen, 1995; Platt and Moortgat, 1999; Platt and Hönninger, 2003). The activation of halogens from the aerosols or the ice surface by $\mathrm{HOBr}$ leads to a sudden increase of bromine concentration in the air residing in the boundary layer; this process is called "bromine 
explosion" (Platt and Janssen, 1995; Platt and Lehrer, 1997; Wennberg, 1999). Reviews of chemical reaction mechanisms describing the lower tropospheric ozone depletion are given by Platt and Hönninger (2003), Simpson et al. (2007), and Abbatt et al. (2012).

To date, a number of numerical studies have been conducted with different degrees of physical dimensionality. Since the 1990s, box models were used to capture the temporal evolution of the chemical species and to investigate the recycling of halogen species on the surface of aerosol or ice covered by snow (Fan and Jacob, 1992; Tang and McConnell, 1996; Sander et al., 1997; Michalowski et al., 2000). More recently, box model studies (Sander et al., 2006; Morin et al., 2008; Sander and Morin, 2010) focus on the role of calcium carbonate precipitation in the triggering of bromine explosion. The coupling of $\mathrm{HO}_{\mathrm{x}}, \mathrm{NO}_{\mathrm{x}}$ and halogen chemistry is investigated by Chen et al. (2007), Bloss et al. (2010) and Liao et al. (2011). In these box models, different scenarios have been investigated explicitly or implicitly to include the key heterogeneous reactions occurring at the aerosol surface or at the snow/ice surface.

Moreover, models with higher physical dimension were developed. Lehrer et al. (2004) propose the primary source of the reactive halogens to be the sea ice surface by using a 1-D model. The coupled snow-gas phase chemistry is intensely studied by Thomas et al. $(2011,2012)$ using a 1-D snow-atmosphere model (MISTRA-SNOW) developed from the 1-D atmospheric boundary layer model MISTRA (von Glasow et al., 2002a, b; von Glasow and Crutzen, 2004; Piot and von Glasow, 2008, 2009). In the MISTRA-SNOW model, special attention is paid to the interaction between bromine- and nitrogen-containing species over snow covered regions. The importance of the bromine reactivation on aerosol and snow is also addressed. The snowpack is suggested as a potential source by Toyota et al. $(2011,2013)$ using different models to analyze the air-snowpack interaction. Zeng et al. $(2003,2006)$ were the first to implement a 3-D model for the estimation of ozone depletion using $\mathrm{BrO}$ measurements from the satellite vertical column density (VCD). Zhao et al. (2008) propose that the aerosols from the frost flowers might be the major source of reactive halogens using a global 3-D model. Yang et al. $(2008,2010)$ show that in a stormy blowing-snow situation, the main bromine contribution comes from the blowing snow particles lifted by the wind during the ozone depletion event. This is confirmed by the measurements of Jones et al. $(2009,2010)$ in the Antarctic, who identify weather conditions under which the ozone depletion event is more or less likely to occur. In these models, the coupling of the bromine chemistry and the wind speed as well as the air temperature is parameterized and discussed in connection with the bromine explosion, the ozone depletion, and the local atmospheric conditions.

The recycling of the halogens at the saline surface attracts more attention, since the chemical reactions involved may occur on different substrates such as the ice surface with or without the liquid-like layer, on snowpacks or on brine layers. Most models apply empirically adjusted deposition and emission rates of the halogen species at the ice/snow surface (Chen et al., 2007; Bloss et al., 2010). Laboratory research of Huff and Abbatt $(2000,2002)$ concerning the activation of $\mathrm{Br}_{2}$ and $\mathrm{BrCl}$ on ice surfaces at $T=233 \mathrm{~K}$ and $248 \mathrm{~K}$ suggests that the heterogeneous reaction between the gas molecules $(\mathrm{HOBr})$ and the adsorbed compounds $\left(\mathrm{Br}^{-}\right)$ at the ice surface closely resembles a collision mechanism on the solid surface, which is of first order. This implies that the halide-ice reactive surface behaves more like a solid rather than a liquid layer in this temperature range, and the transfer of the gas to the ice surface is the rate-determining step. Recently, a quasi-liquid layer on snow/ice was studied (Boxe and Saiz-Lopez, 2008; Thomas et al., 2011; Toyota et al., 2013), accounting for both the aqueous reactions in the liquid-like layer and the gas transfer between the ice/snow surface and the ambient/interstitial gas. Abbatt et al. (2010) and Oldridge and Abbatt (2011) experimentally investigated the oxidation of bromide from frozen salt solutions, and their results also suggest the existence of a concentrated brine layer or a liquid-like structure on the ice surface.

Even though these studies exist, presently insufficient results are available on the analysis of a suitable chemical reaction mechanism. Little is known about the relative importance of each reaction in the complex reaction mechanism at different times, and the role of physical properties such as the influence of boundary layer height, is not clear enough. Moreover, the present literature lacks a detailed discussion on how ozone depletion is altered by the presence of $\mathrm{NO}_{\mathrm{x}}$. In order to address these issues, a photochemical box model is developed. The major focus of the present study is the relative importance of each reaction and how the key metrics such as the boundary layer height affect the timescale of the ozone depletion event. Thus, a simplified treatment of the heterogeneous reactions is adopted. It is assumed that the saline snow/ice surface is the source of the halogen species. The collisions between $\mathrm{HOBr}$ molecules from the overlying atmosphere and the saline surface determine the liberation of $\mathrm{Br}_{2}$ and $\mathrm{BrCl}$ from the surface back to the surroundings. The heterogeneous reactions occurring at the aerosol surfaces help to reactivate the inert halogen from the hydrogen halides. The quasi-liquid layer on the ice surface is not taken into account in the present study. The following are the main objectives of the present research.

1. Study of the temporal variation of the chemical species and reaction rates, and thus, identify the dominant reactions at different times during the ozone depletion event.

2. Analysis of the influence of the height of the boundary layer and surface properties such as the $\mathrm{HOBr}$ uptake coefficient. 
3. Identification of the significance of each chemical reaction and the transport features by a sensitivity analysis.

4. Investigation of the role of $\mathrm{NO}_{\mathrm{x}}$ and chlorine chemistry on bromine release and ozone depletion.

\section{Mathematical model and methods}

The present model consists of a system of homogeneous chemical reactions, and it may be written in the form

$$
\frac{\mathrm{d} c}{\mathrm{~d} t}=\boldsymbol{f}(\boldsymbol{c}, \boldsymbol{k})
$$

with $\left.\boldsymbol{c}\right|_{t=0}=\boldsymbol{c}_{0}$, where $\boldsymbol{c}$ denotes the species concentration column vector. Equation (1) may represent complex chemical processes, $\boldsymbol{k}$ is the vector of the reaction-rate constants, and $t$ denotes time. Solution of the stiff ordinary differential Eq. (1) is achieved using the software KINAL (Turanyi, 1990), which is an open-source software programmed in FORTRAN language solving the discretized system of chemical kinetic equations with a fourth-order semi-implicit Runge-Kutta method.

\subsection{Sensitivity analysis}

In a complex chemical reaction system, it is difficult to see, which chemical reactions are more important than others. However, this information is very useful to gain insight and a better understanding of the kinetic behavior. In this situation, a sensitivity analysis is helpful to acquire a deeper knowledge about the chemical reactions system. An element of the local relative sensitivity matrix can be written as

$S_{i j}=\frac{\partial \ln c_{i}}{\partial \ln k_{j}}$,

where $c_{i}$ is the concentration of the $i$ th species, and $k_{j}$ is the rate constant of $j$ th reaction. The concentration sensitivity matrix, $S_{i j}$, is a function of time, and it represents the effect of the change of the $i$ th concentration caused by a change of the $j$ th reaction rate at different times. The matrixdecomposed method (Valko and Vajda, 1984) is embedded in KINAL to perform the sensitivity analysis.

\subsection{Reaction schemes}

The reactions are listed in the Supplement and the reaction rates are calculated at temperature $T=258 \mathrm{~K}$ and pressure $p=1 \mathrm{~atm}$. Reaction numbers in the following text refer to the table in the Supplement. Three different chemical reaction schemes are studied. The first one concerns bromine as the only halogen species. The second reaction scheme is an extension of the first one, where nitrogen containing species and reactions are added, and the third chemical reaction scheme adds chlorine and chlorine containing reactions to the extended reaction scheme. Details of the chemical mechanisms and the initial conditions will be given in the results section.

In the present chemical reaction mechanisms, the total halogen loading in the atmosphere is determined by the heterogeneous reactions

$\mathrm{HOBr}+\mathrm{H}^{+}+\mathrm{X}^{-} \stackrel{\text { ice/snow }}{\longrightarrow} \mathrm{BrX}+\mathrm{H}_{2} \mathrm{O}$,

where Reaction (R14) refers to $\mathrm{X}=\mathrm{Br}$ and Reaction (R129) to $\mathrm{Cl}$. These heterogeneous reactions occur at the sea ice surface covered by snow. The inert halogen ions are activated from the fresh sea ice, leading to an increase of the halogen concentrations in the air.

Moreover, the liquid aerosols could offer a possible location for the absorption of gaseous HOBr and HX (Sander and Crutzen, 1996),

$\mathrm{HOBr}+\mathrm{HX} \stackrel{\text { aerosol }}{\longrightarrow} \mathrm{BrX}+\mathrm{H}_{2} \mathrm{O}$,

where Reaction (R13) refers to $\mathrm{X}=\mathrm{Br}$ and Reaction (R128) to $\mathrm{Cl}$. Here, active halogen species of $\mathrm{BrX}$ are reformed from $\mathrm{HX}$ at the aerosol surface before they are emitted into the surrounding environment.

It is essential to precisely parameterize the multiphase reaction rates and their rate constants because of their high impact on the entire process. The following sections describe the present formulation for aerosols and for ice/snowpacks.

\subsubsection{Heterogeneous reactions for aerosols}

According to Schwartz (1986), the production rate of $\mathrm{Br}_{2}$ molecules for Reaction (R13) is given as

$\frac{\mathrm{d}\left[\mathrm{Br}_{2}\right]}{\mathrm{d} t}=-\frac{\mathrm{d}[\mathrm{HOBr}]}{\mathrm{d} t}=k_{\mathrm{R} 13}[\mathrm{HOBr}]$

with the first order heterogeneous reaction-rate constant

$k_{\mathrm{R} 13}=\left(\frac{a}{D_{g}}+\frac{4}{v_{\text {therm }} \gamma}\right)^{-1} \alpha_{\text {eff }}$.

The ratio $a / D_{g}$ in Eq. (4) represents the molecular diffusion limit, where $a$ is the aerosol radius and $D_{g}$ denotes the molecular diffusivity in the gas phase. In the present model, $D_{g}=0.2 \mathrm{~cm}^{2} \mathrm{~s}^{-1}$, and $a=0.45 \mu \mathrm{m}$. The remaining contribution on the right-hand side of Eq. (4) accounts for the collision frequency at the surface. The mean molecular speed, $v_{\text {therm }}$ of $\mathrm{HOBr}$ is given by $v_{\text {therm }}=\sqrt{8 R T /\left(\pi M_{\mathrm{HOBr}}\right)}$, where $M_{\mathrm{HOBr}}$ is the molar mass of HOBr. $R$ denotes the universal gas constant, and $T$ is the absolute temperature. In Eq. (4), $\gamma$ denotes the uptake coefficient of $\mathrm{HOBr}$ on sea salt aerosols. Considering Eq. (4), it is seen that for aerosols with low $\gamma$, thermal collision-induced reactions are favored, 
whereas in case of a high value of $\gamma$, diffusion is the limiting process.

The surface-volume coefficient, $\alpha_{\mathrm{eff}}$, is the ratio of the total aerosol surface area, $A_{\text {aerosol }}$, and the total volume, $V$ :

$\alpha_{\mathrm{eff}}=\frac{A_{\text {aerosol }}}{V}$.

The evaluation of the value of the uptake coefficient, $\gamma$, and the surface-volume coefficient, $\alpha_{\text {eff }}$, is needed to determine the rate coefficient of the heterogeneous Reaction (R13).

According to Lehrer et al. (2004), $\gamma=0.12$ is obtained for a gas mixing ratio of $10 \mathrm{ppt} \mathrm{HBr}$. Details of this calculation are given in Sect. 2 of the Supplement. If the aerosol particles are assumed to be uniformly distributed, using the data provided by Staebler et al. (1999), the aerosol volume fraction is calculated to equal $10^{-11} \mathrm{~cm}^{3} \mathrm{~cm}^{-3}$, and an effective aerosol surface area of $10^{-6} \mathrm{~cm}^{2}$ is offered per cubic centimeter of air volume, which yields $\alpha_{\text {eff }}=10^{-6} \mathrm{~cm}^{-1}$. The first-order reaction-rate constant for Reaction (R13) can then be calculated as $k_{\mathrm{R} 13}=6.14 \times 10^{-4} \mathrm{~s}^{-1}$ for the mixing ratio $10 \mathrm{ppt}$ of $\mathrm{HBr}$.

Considering the chlorine containing mechanism in Reaction $(\mathrm{R} 128), \mathrm{BrCl}$ is produced via the corresponding heterogeneous reaction. Similarly, if the mixing ratio of $\mathrm{HCl}$ is $10 \mathrm{ppt}$, the first-order reaction-rate constant of $k_{\mathrm{R} 128}=$ $1.61 \times 10^{-5} \mathrm{~s}^{-1}$ is obtained.

\subsubsection{Heterogeneous reactions for ice/snowpacks}

For Reactions (R14) and (R129), in which the ice/snowpack offers the possible reaction site, the change in concentration of $\mathrm{HOBr}$ yields

$$
\frac{\mathrm{d}[\mathrm{HOBr}]}{\mathrm{d} t}=-k_{\mathrm{d}}[\mathrm{HOBr}]
$$

where the deposition-rate constant, $k_{\mathrm{d}}$, is

$k_{\mathrm{d}}=\frac{v_{\mathrm{d}}}{L_{\text {mix }}} \beta$.

$k_{\mathrm{d}}$ depends on the deposition velocity, $v_{\mathrm{d}}$ at the ice/snow surfaces, the typical height of the mixing layer, $L_{\text {mix }}$, and the total reactive surface area offered by ice/snow, which is considered through a reactive surface ratio coefficient, $\beta$. They are specified as follows.

$v_{\mathrm{d}}$ can be written as the sum of three resistances: the aerodynamic resistance, $r_{a}$, the quasi-laminar layer resistance, $r_{b}$, and the surface resistance, $r_{c}$ (Seinfeld and Pandis, 1998),

$v_{\mathrm{d}}=\left(r_{a}+r_{b}+r_{c}\right)^{-1}$.

The estimation of the values for the deposition velocity is taken following the work of Huff and Abbatt $(2000,2002)$. The first contribution, $r_{a}$, describes the resistance of the turbulent transport to bring the gas from the atmosphere down to the surface, and it is approximated as $1 /\left(u \kappa^{2}\right)\left(\ln \left(z / z_{0}\right)\right)^{2}$, where $u=8 \mathrm{~m} \mathrm{~s}^{-1}$ (Beare et al., 2006) is the wind speed, and $\kappa=0.4$ is the von Karman constant. $z$ denotes the height of the surface layer, which is $10 \%$ of the boundary layer height, $z=0.1 L_{\text {mix }}$, and $z_{0}$ is the surface roughness length, for which a constant value of $10^{-5} \mathrm{~m}$ is used for the ice surface (Stull, 1988; Huff and Abbatt, 2000, 2002). Thus, the value of $r_{a}$ depends on the local transport properties wind speed and boundary layer height. The quasi-laminar layer resistance, $r_{b}$, represents the ability of molecular diffusion to transfer gas across a liquid-laminar layer above the surface, and it is given as $r_{b}=z_{0} / D_{g}$. The resistance due to the reaction loss, $r_{c}$, is expressed as $4 /\left(v_{\text {therm }} \gamma\right)$. A constant uptake coefficient of $\gamma=0.06$ is taken after Sander and Crutzen (1996); this includes the assumption that $\mathrm{H}^{+}$and halogen ions are inexhaustible at the ice/snow surface.

$L_{\text {mix }}$ in Eq. (7) stands for the typical height of the stable boundary layer. Typical magnitudes of the stable boundary layer height observed in polar regions range from a near-zero value to over $1000 \mathrm{~m}$ (Stull, 1988), depending, for instance, on the wind speed and the intensity of temperature inversion. In the present model, different boundary layer heights of $200 \mathrm{~m}$ (suggested by Beare et al. (2006) and used by Evans et al., 2003), $500 \mathrm{~m}$ (used by Oltmans et al., 2012) and $1000 \mathrm{~m}$ (used by Lehrer et al., 2004) are considered. The corresponding deposition velocities for the three boundary layer heights are $0.605 \mathrm{~cm} \mathrm{~s}^{-1}, 0.536 \mathrm{~cm} \mathrm{~s}^{-1}$ and $0.491 \mathrm{~cm} \mathrm{~s}^{-1}$. These values are in a reasonable range for the $\mathrm{HOBr}$ deposition velocity (Sander and Crutzen, 1996; Adams et al., 2002; Yang et al., 2005).

$\beta$ is introduced in Eq. (7), defined as the ratio of the total reactive surface area offered by the ice/snow surface and the flat surface area. For a flat surface of pure ice, $\beta$ equals unity. However, considering the porous properties of the contaminated snow above the ice surface, larger surface areas may be offered by the ice/snow surface. The physical structure of the surface and its roughness may also increase the reactive surface area, for instance, through frost flowers, because of their sharp angular features (Rankin et al., 2002). The lifted snow pumped by the wind near the surface may also increase the total reactive surface area. Because of the uncertainty of the reactive surface area offered by the saline surface, a parameter study is performed for a proper range of $\beta$.

If the chlorine mechanism is discarded, all $\mathrm{HOBr}$ molecules residing at the ice/snow surface are converted into $\mathrm{Br}_{2}$ through Reaction (R14), and the $\mathrm{Br}_{2}$ is emitted into the ambient air. For $\beta=1.0$, the reaction-rate constants $k_{\mathrm{R} 15}$ for Reaction (R14) are calculated as $3.03 \times 10^{-5} \mathrm{~s}^{-1}$, $1.072 \times 10^{-5} \mathrm{~s}^{-1}$ and $4.91 \times 10^{-6} \mathrm{~s}^{-1}$ for the boundary layer heights $L_{\text {mix }}=200 \mathrm{~m}, 500 \mathrm{~m}$, and $1000 \mathrm{~m}$, respectively.

However, if the chlorine mechanism is added, reaction

$\mathrm{HOBr}+\mathrm{H}^{+}+\mathrm{Cl}^{-} \stackrel{\text { snow } / \text { ice }}{\longrightarrow} \mathrm{BrCl}+\mathrm{H}_{2} \mathrm{O}$

competes with Reaction (R14) for the $\mathrm{HOBr}$ molecules, and the reaction-rate ratio, $K_{\mathrm{Br}_{2} / \mathrm{BrCl}}=k_{\mathrm{R} 14} / k_{\mathrm{R} 129}$, of 
Reactions (R14) and (R129) determines the formation ratio of $\mathrm{Br}_{2}$ and $\mathrm{BrCl}$ molecules through the heterogeneous activation from the ice/snowpack. The value of $K_{\mathrm{Br}_{2} / \mathrm{BrCl}}$ varies between 0.8 and 1.4 (Foster et al., 2001). Michalowski et al. (2000) found that the ozone depletion rate is very sensitive to the production-rate ratio of $\mathrm{Br}_{2}$ and $\mathrm{BrCl}$. Therefore, the relation between the production-rate ratio and ozone depletion time is investigated in the present study; the default value is taken to be unity.

\subsection{Photolysis reactions}

The photolysis reaction rates, $J$, are evaluated by using a three-coefficient formula, where the surface albedo equals unity (Röth, 1992, 2002):

$J=J_{0} \exp (b[1-\sec (c \chi)])$.

$\chi$ denotes the solar zenith angle (SZA), and the coefficients $J_{0}, b$, and $c$ are determined from the data at $\chi=0^{\circ}, 60^{\circ}$, and $90^{\circ}$. The values of these coefficients for photolyzable compounds are listed in the Supplement. In this model, the average photolysis reaction rates are used under the condition of a SZA of $80^{\circ}$. It is found that the variation of SZA has little effect on the temporal evolutions of mixing ratios of the ozone and halogen species (see Sect. 3 of the Supplement).

In the next section, results of the numerical computations are presented with emphasis on the different chemical reaction schemes presented above.

\section{Results and discussion}

First, the chemical reaction mechanism without any $\mathrm{NO}_{\mathrm{x}}-$ and chlorine-related reactions is analyzed. The chemical reaction scheme involves 55 chemical reactions (R1-R55) presented in the Supplement) and 30 species. This mechanism will be referred to as "bromine-only mechanism" in the remainder of the paper.

In a second step, 31 reactions (R56-R86) and 9 nitrogencontaining species are added in order to investigate the effect of $\mathrm{NO}_{\mathrm{x}}$ species on the ozone depletion. It is assumed that the same values for the uptake coefficient $(\gamma=0.06)$ are taken for the $\mathrm{NO}_{\mathrm{x}}$-related heterogeneous Reactions (R83), (R85), and (R86). Since $\mathrm{NO}_{\mathrm{x}}$ is converted to peroxyacytyl nitrate (PAN), which photolyzes very slowly, fluxes of nitrogen-containing species produced from the snow are added to the model, they are listed in Table 1 . The emission rates of $\mathrm{NO}, \mathrm{NO}_{2}, \mathrm{H}_{2} \mathrm{O}_{2}$, and $\mathrm{HCHO}$ are estimated based on the measurements by Jones et al. $(2000,2001)$, and Jacobi et al. (2002), and the production ratio of $\mathrm{HONO}$ and $\mathrm{NO}_{2}$ is unity (Grannas et al., 2007). The photolysis of nitrate in the snowpack is assumed to be the major source of the nitrogencontaining fluxes.

Finally, 49 chlorine-related reactions (R87-R135) and 10 chlorine containing species are added to the extended reaction mechanism.
Table 1. Emission fluxes from the snow.

\begin{tabular}{lc}
\hline Species & $\left.\begin{array}{c}\text { Emission rates } \\
{[\text { molec. cm }}\end{array}{ }^{-2} \mathrm{~s}^{-1}\right]$ \\
\hline $\mathrm{NO}$ & $1.6 \times 10^{7}$ \\
$\mathrm{NO}_{2}$ & $1.6 \times 10^{7}$ \\
$\mathrm{HONO}$ & $1.6 \times 10^{7}$ \\
$\mathrm{H}_{2} \mathrm{O}_{2}$ & $1.6 \times 10^{8}$ \\
$\mathrm{HCHO}$ & $6.0 \times 10^{7}$ \\
\hline
\end{tabular}

Table 2. Initial gas composition (ppm is parts per million, ppb is parts per billion, ppt is parts per trillion).

\begin{tabular}{lr}
\hline Species & Mixing ratio \\
\hline $\mathrm{O}_{3}$ & $40 \mathrm{ppb}$ \\
$\mathrm{Br}_{2}$ & $0.3 \mathrm{ppt}$ \\
$\mathrm{HBr}$ & $0.01 \mathrm{ppt}$ \\
$\mathrm{CH}_{4}$ & $1.9 \mathrm{ppm}$ \\
$\mathrm{CO}_{2}$ & $371 \mathrm{ppm}$ \\
$\mathrm{CO}$ & $132 \mathrm{ppb}$ \\
$\mathrm{HCHO}$ & $100 \mathrm{ppt}$ \\
$\mathrm{CH}_{3} \mathrm{CHO}$ & $100 \mathrm{ppt}$ \\
$\mathrm{C}_{2} \mathrm{H}_{6}$ & $2.5 \mathrm{ppb}$ \\
$\mathrm{C}_{2} \mathrm{H}_{4}$ & $100 \mathrm{ppt}$ \\
$\mathrm{C}_{2} \mathrm{H}_{2}$ & $600 \mathrm{ppt}$ \\
$\mathrm{C}_{3} \mathrm{H}_{8}$ & $1.2 \mathrm{ppb}$ \\
$\mathrm{NO}$ & $5 \mathrm{ppt}$ \\
$\mathrm{NO}_{2}$ & $10 \mathrm{ppt}$ \\
$\mathrm{Cl}_{2}$ & $0.3 \mathrm{ppt}$ \\
$\mathrm{HCl}_{\mathrm{H}_{2} \mathrm{O}}$ & $0.01 \mathrm{ppt}$ \\
\hline
\end{tabular}

The initial mixing ratios of gas-phase species are listed in Table 2. The prescribed initial triggers of bromine species in the air are $0.3 \mathrm{ppt} \mathrm{Br}_{2}$ and $0.01 \mathrm{ppt} \mathrm{HBr}$. This small amount of bromine could originate from the degradation of natural organohalogen compounds, for instance $\mathrm{CHBr}_{3}$ (Tang and McConnell, 1996). Species not listed in Table 2 have an initial mixing ratio of zero (except for natural air).

The following subsections concern the presentation and discussion of the results of the three above-mentioned chemical reaction schemes for the ozone depletion.

\subsection{Bromine-only mechanism}

Figure 1 displays the mixing ratios of the relevant species as a function of time for three different boundary layer heights of $200 \mathrm{~m}, 500 \mathrm{~m}$, and $1000 \mathrm{~m}$, and Fig. 2 shows a column presentation of the top panel in Fig. 1. It can be seen that ozone depletion starts after 5 days and lasts for about $40 \mathrm{~h}$ for a $200 \mathrm{~m}$ boundary layer thickness. Before day 5 , little ozone is consumed. At this early stage, the mixing ratios of $\mathrm{HOBr}$ and $\mathrm{BrO}$ show an exponential growth; these two species constitute the majority of contributions of bromine 


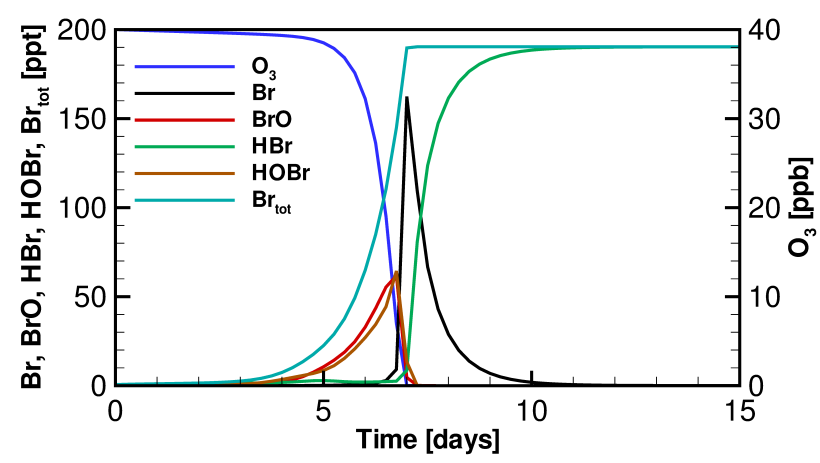

(a)

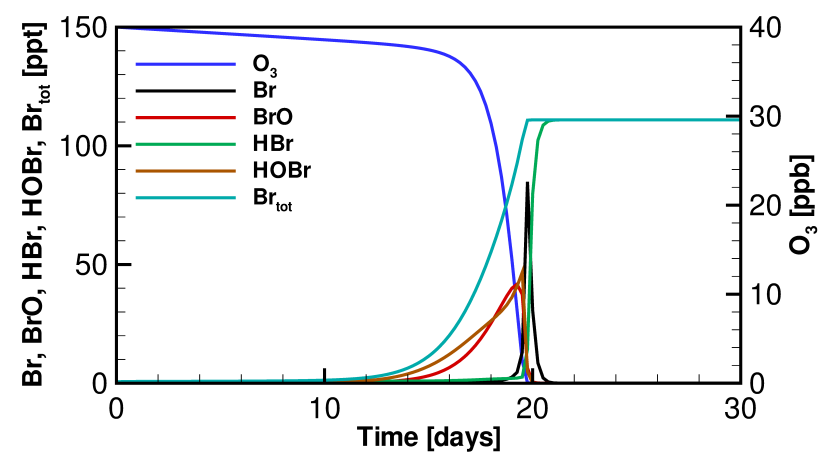

(b)

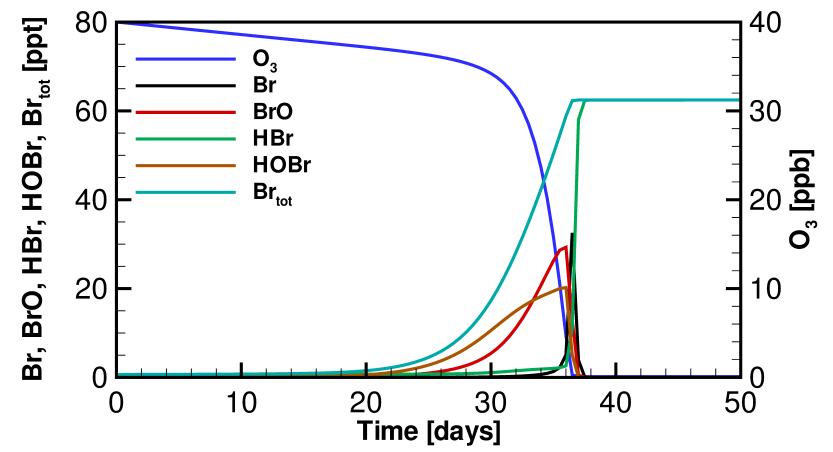

(c)

Fig. 1. Time variation of the mixing ratios of ozone and bromine using the bromine-only mechanism for a boundary layer height of (a) $200 \mathrm{~m}$, (b) $500 \mathrm{~m}$, and (c) $1000 \mathrm{~m}$.

species. Due to the existence of ozone, the $\mathrm{Br}$ atoms are instantly converted to $\mathrm{BrO}$ and, thus, they can hardly be observed at this time. As the mixing ratio of $\mathrm{HOBr}$ increases, a large amount of reactive bromine is released from the saline surface, leading to an explosive increase of the total bromine loading and a rapid decrease of ozone in the atmosphere. After 6 days, BrO builds up to reach a peak level of $60 \mathrm{ppt}$, and then it rapidly decreases. When the mixing ratio of $\mathrm{HOBr}$ increases to its maximum value of about $65 \mathrm{ppt}$, the ozone mixing ratio falls below $1 \mathrm{ppb}$. Thereafter, the mixing ratio of $\mathrm{HOBr}$ falls rapidly, the mixing ratio of the $\mathrm{Br}$ atom abruptly builds up to be the main constituent of the bromine loading,

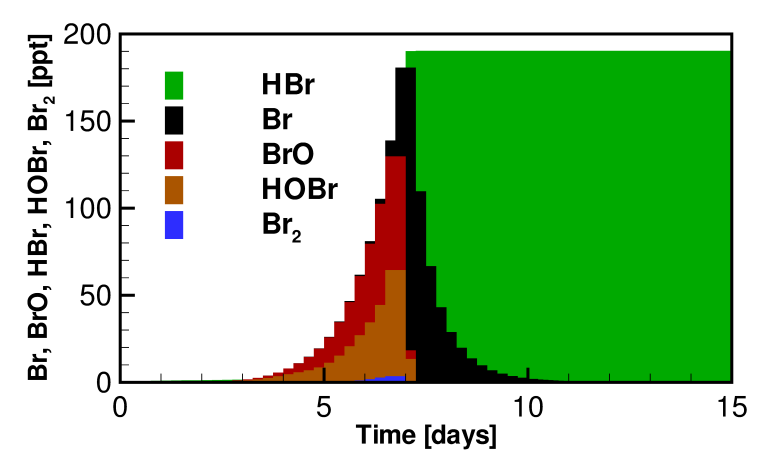

Fig. 2. Temporal evolution of the mixing ratios of ozone and bromine using the bromine only mechanism for a boundary layer height of $200 \mathrm{~m}$.

which increases to its maximum value of about $160 \mathrm{ppt}$. This large amount of $\mathrm{Br}$ then is removed by aldehydes (for instance $\mathrm{HCHO}$ and $\mathrm{CH}_{3} \mathrm{CHO}$ ) in the natural air, forming $\mathrm{HBr}$. At the end of the depletion event, a high level of $\mathrm{HBr}$ is left in the air, which is confirmed by the aerosol measurements of Langendörfer et al. (1999).

Considering the temporal behavior of the species as discussed above, the whole ozone depletion process may be divided into three time periods. At the beginning of the event, the gaseous halogen mixing ratios in the air are low, only a small fraction of ozone is slowly consumed - this period may be called "induction stage", in which the ozone depletion rate is less than $0.1 \mathrm{ppbh}^{-1}$. This period is followed by the "depletion stage", where a large amount of inert halogens are released by frequent collisions between the saline surface and $\mathrm{HOBr}$ molecules in the air. The ozone in the atmospheric boundary layer is severely consumed at this stage, and the depletion rate is higher than $0.1 \mathrm{ppbh}^{-1}$. In the last time period, the "end stage", the mixing ratio of ozone drops to values below $10 \%$ of its original value ( $4 \mathrm{ppb}$ in this study). The remaining halogen species are hydrogen halides, and the total halogen mixing ratio remains almost constant. For a $200 \mathrm{~m}$ boundary layer height and $0.3 \mathrm{ppt}$ initial $\mathrm{Br}_{2}$ the "induction stage" and the "depletion stage" last for 5.1 days and 1.8 days, respectively. For a reduced value of $0.1 \mathrm{ppt}$ initial $\mathrm{Br}_{2}$ mixing ratio, the "induction stage" is prolonged, and for a higher initial value of $0.5 \mathrm{ppt}$ it is reduced, whereas the duration of the "depletion stage" is hardly affected. Thus, it is concluded that the ozone depletion is caused by the activated bromine from the sea ice surface, whereas the initial bromine serves as a trigger to the ozone depletion event.

When $L_{\text {mix }}$ is increased to $500 \mathrm{~m}$ and $1000 \mathrm{~m}$ (see Fig. $1 \mathrm{~b}$, c), the depletion stage is retarded to start after 15 days and 30 days, respectively, and its duration is extended to about 3-5 days. The principal profiles of the mixing ratio of bromine species are similar to those for the $200 \mathrm{~m}$ boundary layer height, but the peak values are considerably lower. The maximum values of the mixing ratio of $\mathrm{BrO}$ are in the range 


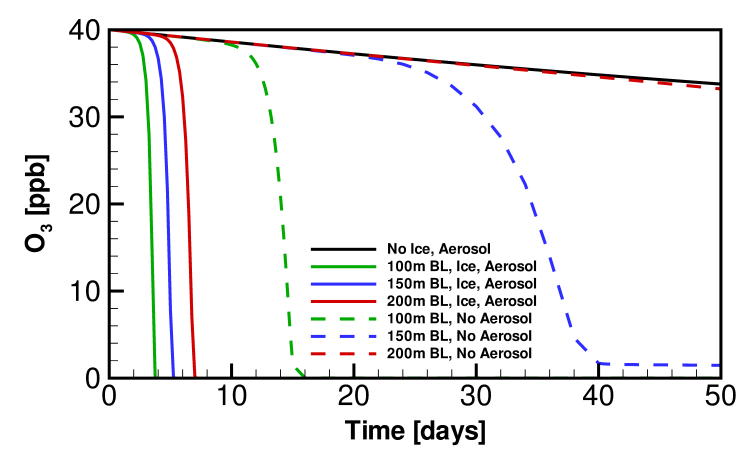

Fig. 3. Effect of the heterogeneous reaction rates on the ozone depletion time.

of 30-40 ppt compared to $60 \mathrm{ppt}$ for $L_{\mathrm{mix}}=200 \mathrm{~m}$. The results for a $1000 \mathrm{~m}$ boundary layer height may be compared with the measurements and simulations of Liao et al. (2012), who found that the mixing ratio of $\mathrm{BrO}$ lies between 20 and $30 \mathrm{ppt}$ and $\mathrm{HOBr}$ around $20 \mathrm{ppt}$.

In order to evaluate the role of the activation process for different types of surfaces, exploratory simulations turning off the activation processes on the aerosol and/or at the ice/snow surface are conducted. The results of the simulations are presented in Fig. 3 for three different values of boundary layer height. It is seen that both the activation processes at the ice/snow surface and the aerosol play a significant role, since each of them lead to strongly enhanced ozone depletion. The existence of the ice/snow surface is the major factor to activate ozone depletion, and the aerosol activation leads to further acceleration of the ozone depletion, because the total halogen loading in the atmosphere is determined by the activation at the ice/snow surface, and the heterogeneous process on the aerosol surface helps to reactivate the halogen stored in hydrogen halides. The simulations show that for a boundary layer height of $200 \mathrm{~m}$ or higher, the ozone depletion event will not happen if either aerosol or ice/snow surface activation is turned off. Thus, both activation processes are needed for a boundary layer higher than $200 \mathrm{~m}$. Since the typical height of the stable boundary layers measured in polar regions vary from $100 \mathrm{~m}$ to $500 \mathrm{~m}$ (Stull, 1988), the remainder of the study concerns a boundary layer height of $200 \mathrm{~m}$.

The reactions directly affecting the ozone mixing ratio are listed in Table 3. Note that the complete mechanism is provided in the Supplement. Reactions (R2), (R6), and (R29) cause ozone formation, whereas Reactions (R1), (R4), (R26), (R30), and (R36) lead to ozone depletion. The temporal evolution of these ozone-relevant reaction rates are plotted in Fig. 4 in logarithmic scale for the case of a $200 \mathrm{~m}$ boundary layer height. The relevance of these reactions is discussed below in connection with the sensitivity analysis, which reveals that the reactions discussed here have a high relative sensitivity and therefore dominate the entire process under consideration. In the top panel of the figure ozone forming
Table 3. List of ozone-relevant reactions (type F: ozone formation; type D: ozone depletion).

\begin{tabular}{llc}
\hline Reaction & No. & Type \\
\hline $\mathrm{O}_{3}+h v \rightarrow \mathrm{O}\left({ }^{1} \mathrm{D}\right)+\mathrm{O}_{2}$ & $(\mathrm{R} 1)$ & $\mathrm{D}$ \\
$\mathrm{O}\left({ }^{1} \mathrm{D}\right)+\mathrm{O}_{2} \rightarrow \mathrm{O}_{3}$ & $(\mathrm{R} 2)$ & $\mathrm{F}$ \\
$\mathrm{Br}+\mathrm{O}_{3} \rightarrow \mathrm{BrO}+\mathrm{O}_{2}$ & $(\mathrm{R} 4)$ & $\mathrm{D}$ \\
$\mathrm{BrO}+h v \stackrel{\mathrm{O}_{2}}{\longrightarrow} \mathrm{Br}+\mathrm{O}_{3}$ & $(\mathrm{R} 6)$ & $\mathrm{F}$ \\
$\mathrm{OH}+\mathrm{O}_{3} \rightarrow \mathrm{HO}_{2}+\mathrm{O}_{2}$ & $(\mathrm{R} 26)$ & $\mathrm{D}$ \\
$\mathrm{OH}+\mathrm{OH} \stackrel{\mathrm{O}_{2}}{\longrightarrow} \mathrm{H}_{2} \mathrm{O}+\mathrm{O}_{3}$ & $(\mathrm{R} 29)$ & $\mathrm{F}$ \\
$\mathrm{HO}_{2}+\mathrm{O}_{3} \rightarrow \mathrm{OH}+2 \mathrm{O}_{2}$ & $(\mathrm{R} 30)$ & $\mathrm{D}$ \\
$\mathrm{C}_{2} \mathrm{H}_{4}+\mathrm{O}_{3} \rightarrow \mathrm{HCHO}+\mathrm{CO}+\mathrm{H}_{2} \mathrm{O}$ & $(\mathrm{R} 36)$ & $\mathrm{D}$ \\
\hline
\end{tabular}

reactions are displayed, and in the bottom panel the rates for ozone depletion reactions are depicted in reverse vertical axial direction. During the ozone induction stage before day 5, the fastest ozone formation reaction is Reaction (R2), whereas the fastest depletion reaction is Reaction (R1). Most of the ozone molecules are involved in this reaction pair during the induction stage. After the initiation of ozone depletion at day 5 , the most rapid ozone consumption occurs through the reaction pair consisting of the formation Reaction (R6) and the depletion Reaction (R4). This reaction pair is about two orders of magnitude faster than the Reaction pair (R1) and (R2) in the depletion stage.

Although most of the ozone molecules are involved in the fastest reaction pairs mentioned above, it is the difference of formation and consumption of these reaction pairs causing the ozone depletion. Therefore, it is interesting to investigate the contributions to the total ozone destruction by various reactions and reaction pairs at different time steps. Figure 5 shows the instantaneous contributions to ozone depletion at day 2 within the induction stage and at day 6 , which is during the depletion stage. In the induction stage, although most of the ozone molecules are involved in the Reaction pair (R1) and (R2) as discussed above, it is seen in the top panel in Fig. 5 that the largest ozone consumption occurs through

$\mathrm{HO}_{2}+\mathrm{O}_{3} \rightarrow \mathrm{OH}+2 \mathrm{O}_{2}$

In contrast, during the depletion stage (cf. Fig. 5b), most of the ozone molecules are consumed through the difference in reaction rates

$\mathrm{Br}+\mathrm{O}_{3} \rightarrow \mathrm{BrO}+\mathrm{O}_{2}$

and

$\mathrm{BrO}+h v \stackrel{\mathrm{O}_{2}}{\longrightarrow} \mathrm{Br}+\mathrm{O}_{3}$.

The difference in reaction rates of Reactions (R4) and (R6) is due to the higher $\mathrm{Br}$ mixing ratio during the ozone depletion stage. The increase of the $\mathrm{Br}$ mixing ratio is mainly attributed by the $\mathrm{BrO} / \mathrm{BrO}$ self-Reaction (R7). This is confirmed by the 


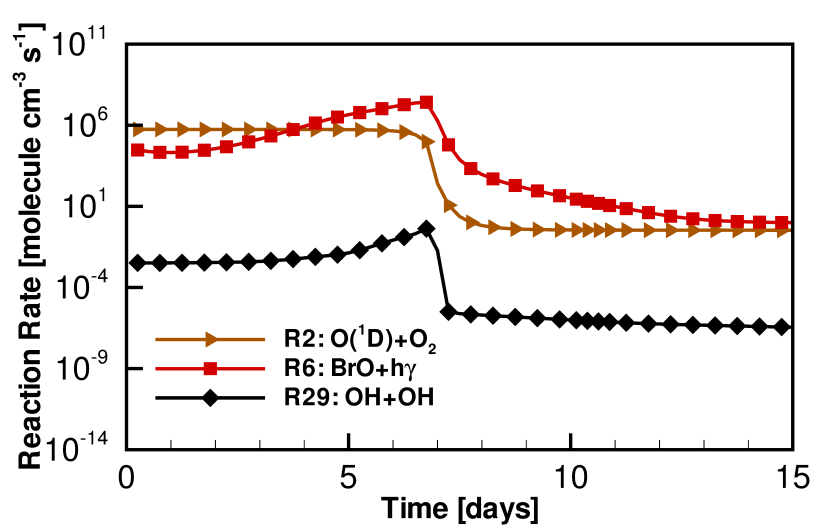

(a)

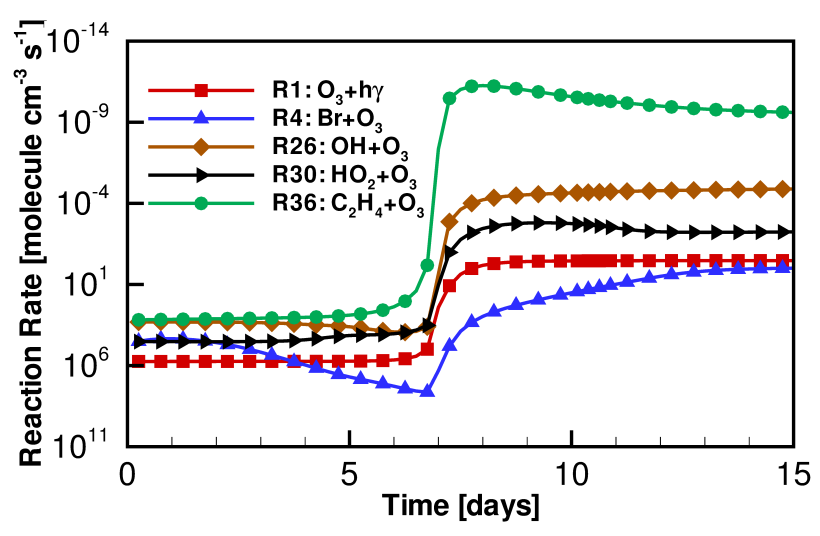

(b)

Fig. 4. Temporal evolution of ozone-relevant reaction rates in a $200 \mathrm{~m}$ boundary layer height: (a) formation, (b) depletion. Note that a reverse direction of vertical axis is used in the bottom panel.

result displayed in Sect. 4 of the Supplement showing the fractions of $\mathrm{Br}$ production at day 6 .

In the present study, the relevance of different chemical reaction steps is discussed in the framework of a sensitivity analysis (see Eq. 2), which is used to reduce the present mechanism to a skeletal reaction scheme for application in 3-D simulations (Cao and Gutheil, 2013, 2014).

Figure 6 shows the instantaneous relative sensitivities for ozone and $\mathrm{BrO}$ at day 6 , which is the time when major ozone depletion occurs. Red and blue bars show the sensitivity coefficients for $\mathrm{BrO}$ and for $\mathrm{O}_{3}$, respectively. They have opposite signs, since ozone is destroyed/formed as $\mathrm{BrO}$ is built up/consumed, where a negative sign corresponds to depletion. Reactions (R4) and (R6), which constitute the fastest ozone reaction pair as mentioned above, have a high impact on the ozone and $\mathrm{BrO}$ concentrations. $\mathrm{HOBr}$ production and destruction reactions, (R9) and (R10), are important since $\mathrm{HOBr}$ is involved in the heterogeneous bromine liberation process. The heterogeneous Reactions (R13) and (R14) are also crucial for the same reason. Thus, it is very important

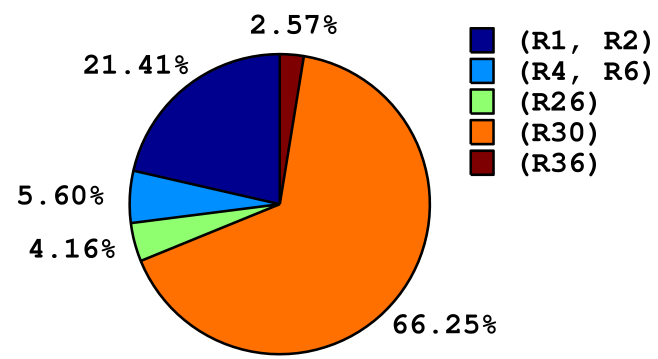

(a)

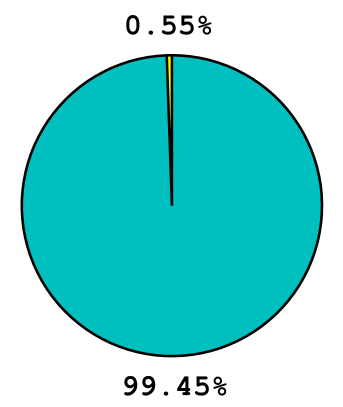

Others

(R4, R6)

(b)

Fig. 5. Instantaneous contribution of various reactions and combinations of reactions to ozone depletion at (a) day 2 (induction stage) and (b) day 6 (depletion stage).

to have a good knowledge of the chemical reaction-rate constants of these reactions because of their dominance of the ozone depletion mechanism. Moreover, the sensitivity analysis may be used to develop a skeletal chemical reaction scheme in removing chemical reaction steps without losing the principal features of the characteristics of the process under consideration. The sensitivities vary with time and chemical species. The reactions with the lowest average sensitivity can be removed from the mechanism without significant change in the modeled results of the temporal evolutions of mixing ratios of the chemical species. The process for the reduction of the chemical reaction mechanism to a suitable skeletal scheme is described by Cao and Gutheil (2013).

The temporal evolutions of the sensitivity of the ozone concentration for the boundary layer height, $L_{\text {mix }}$, the saline surface uptake coefficient, $\gamma$, and the reactive surface ratio, $\beta$, are displayed in Fig. 7. When the depletion process starts after 5 days, the absolute values of these sensitivities increase sharply and peak at about day 7 (cf. Fig. 7). The sensitivity of $\gamma$ is smaller compared to the other two parameters, since collision kinetics is less dominant compared to the transport of the air at the ice/snow surface. Since all the physical properties considered here affect the ozone depletion through the heterogenous reactions, it is demonstrated that the heterogeneous liberation process is very important throughout the ozone depletion stage. Therefore, the effect of these parameters is studied in more detail. 


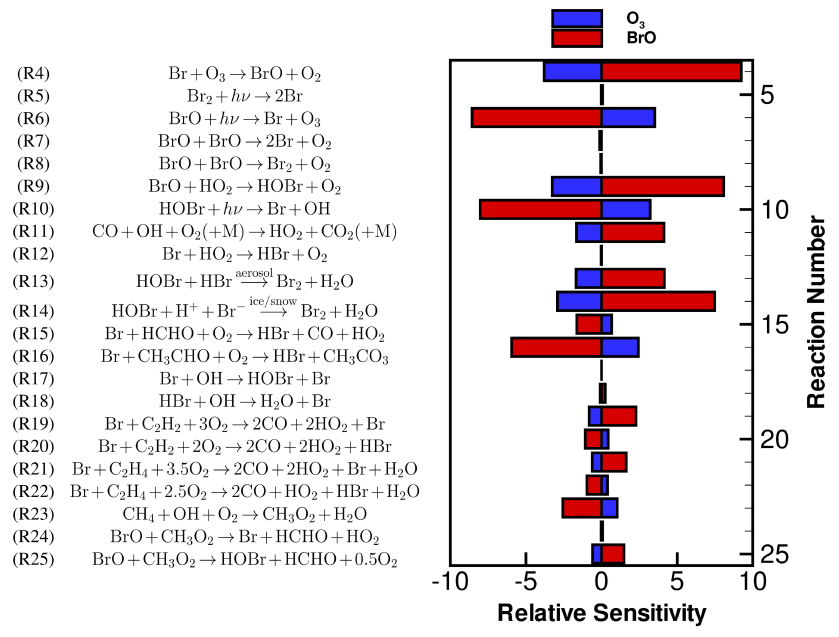

Fig. 6. Instantaneous relative sensitivities of mixing ratios of ozone and $\mathrm{BrO}$ for bromine-containing reactions at day 6 for a $200 \mathrm{~m}$ boundary layer height.

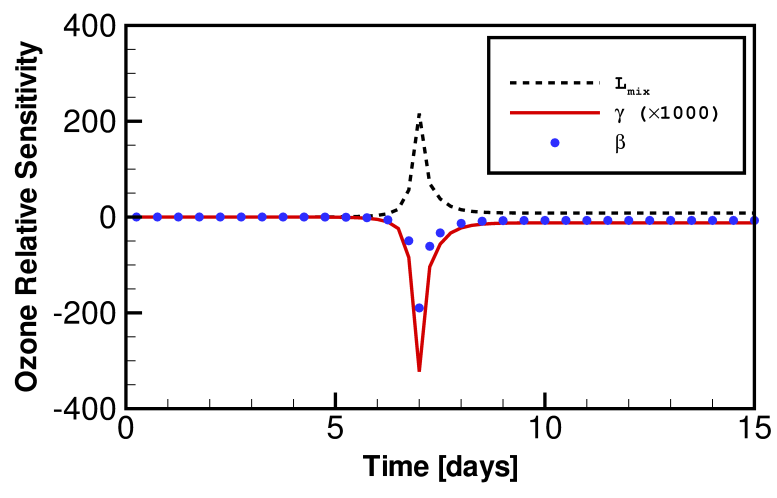

Fig. 7. Temporal evolutions of the sensitivity coefficients of the ozone concentration for $L_{\text {mix }}, \gamma$, and $\beta$.

The positive relative sensitivity of $L_{\text {mix }}$ indicates a slower and less abrupt ozone depletion event for an increased boundary layer height. This is consistent with the results shown in Fig. 1. Similarly, the negative sensitivities of $\gamma$ and $\beta$ show that there is a decrease of the ozone concentration with increased values of $\gamma$ and $\beta$, which means that the ozone depletion is enhanced for higher values. This can be explained as follows: if the reaction probability between $\mathrm{HOBr}$ and the reactive surface is higher (i.e., a larger reactive surface area is offered for the heterogeneous reactions), more bromine atoms are released, leading to an acceleration of ozone depletion.

The reactive surface area ratio, $\beta$, is influenced by the physical structure and the roughness of the fresh ice surface covered by snow, which affects the heterogeneous Reaction (R14). The top panel in Fig. 8 shows the variation of the total ozone depletion time with the reactive surface ratio $\beta$ for different boundary layer heights. The vertical axis

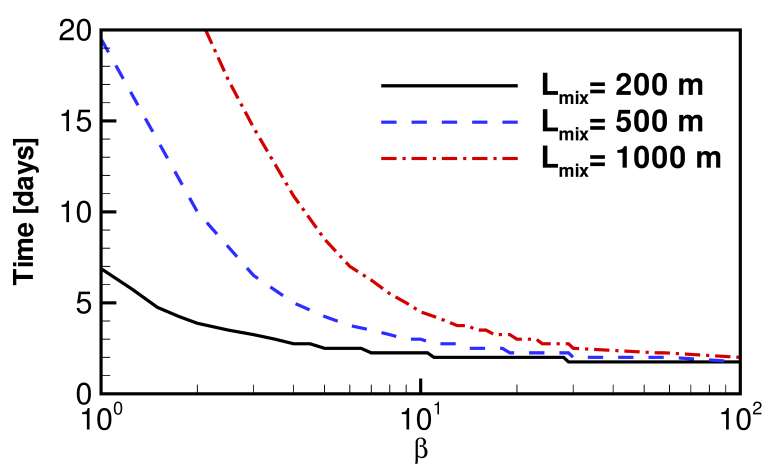

(a)

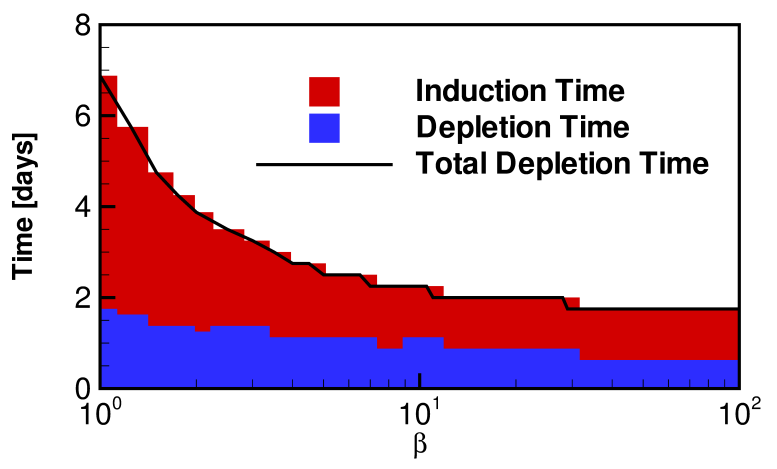

(b)

Fig. 8. Impact of the reactive surface ratio on the (a) total ozone depletion time for three different boundary layer heights, (b) induction and depletion times for a $200 \mathrm{~m}$ boundary layer height.

represents the total time needed until the ozone mixing ratio is less than $4 \mathrm{ppb}$ (10\% of the initial mixing ratio), and the horizontal axis shows the value of $\beta$ in logarithmic scale. In different boundary layer conditions, when $\beta<10$, the increase of $\beta$ significantly reduces the total time including induction and depletion as anticipated. The depletion events with different boundary layer heights are completed within 10 days for $\beta>5$. When $\beta$ approaches 100 , the total depletion time approaches the minimum limit of 2 days independently of the boundary layer height. Thus, the maximum ozone depletion time due to local chemistry cannot fall below 2 days for the range of boundary layer heights under consideration. The bottom panel in Fig. 8 shows that the reduced ozone depletion time with increased $\beta$ is mainly attributable to the reduced "induction time", whereas the "depletion time" remains stable. When $\beta$ approaches the value of 100 , the shortest ozone depletion event consists of $28 \mathrm{~h}$ induction time and $20 \mathrm{~h}$ depletion time. Bottenheim et al. (1986), Tuckermann et al. (1997) and Jones et al. (2006) observe an extremely rapid ozone decrease with a drop of $30 \mathrm{ppb}$ within several hours. However, it is usually assumed that most of this rapid decrease is caused by the transport of ozone-lacking air parcels to the measuring location (Simpson et al., 2007). This unsolved question of the importance 
of chemistry versus transport could be addressed through the consideration of the horizontal transport process, which is beyond the scope of the present study. However, a 3-D model including the modeling of the turbulent transport of air parcels in the framework of a large eddy simulation using a skeletal chemical reaction scheme for the ozone depletion will be available soon (Cao and Gutheil, 2013, 2014).

The following sections concern the extension of the present bromine mechanism through chemical reactions including $\mathrm{NO}_{\mathrm{x}}$ and chlorine and related chemical reactions.

\section{2 $\mathrm{NO}_{\mathrm{x}}$-related chemical reaction mechanism}

The role of $\mathrm{NO}_{\mathrm{x}}$ chemistry is investigated by adding Reactions (R56) to (R86) to the present bromine-only chemical reaction system (see Supplement). Nine chemical species and 31 chemical reactions are added to the bromine-only mechanism.

Figure 9 shows the temporal evolution of the mixing ratios of ozone, bromine and $\mathrm{NO}_{\mathrm{x}}$ species for a boundary layer height of $L_{\mathrm{mix}}=200 \mathrm{~m}$ using the extended mechanism. The time lengths of the induction and depletion stages in this situation are 3.4 days and 1 day, respectively. The $\mathrm{NO}_{\mathrm{x}}$ mixing ratio is mostly between $10 \mathrm{ppt}$ and $20 \mathrm{ppt}$, which compares well with the results of Ridley et al. (2003). During the ozone destruction period, $\mathrm{NO}_{\mathrm{x}}$ species and fluxes of nitrogen-containing species from the snow (see Table 1) are converted into $\mathrm{BrONO}_{2}$ and other nitrogen-containing compounds such as $\mathrm{BrNO}_{2}$.

The major sink of the nitrogen is attributable to PAN. The mixing ratio of PAN increases until ozone is completely consumed, this enhancement of PAN during the ozone depletion time is also observed in the last period of the measurements by Bottenheim et al. (1986) conducted at Alert, Canada, for nitrogen containing compounds. After the total ozone depletion in the air, the mixing ratio of PAN shows little variation. The present study reveals that during the ozone depletion stage the mixing ratio of $\mathrm{NO}_{\mathrm{x}}$ decreases, and when the ozone is almost completely consumed the $\mathrm{NO}_{\mathrm{x}}$ mixing ratio increases. This evolution of the mixing ratio of $\mathrm{NO}_{\mathrm{x}}$ is consistent with the measurements reported by Beine et al. (2002a, b) at Alert in the polar spring in the year 2000. The addition of $\mathrm{NO}_{\mathrm{x}}$-related chemistry causes an increase of the peak value of $\mathrm{HOBr}$ in the atmosphere from $65 \mathrm{ppt}$ with the bromine only mechanism to $110 \mathrm{ppt}$ as shown in the bottom panel in Fig. 9. The additional HOBr flux is generated by the $\mathrm{BrONO}_{2}$ hydrolysis process in Reactions (R83) and (R86) at the aerosol surfaces and in the ice/snowpack. Using the extended chemical reaction scheme, the total bromine mixing ratio increases from about $190 \mathrm{ppt}$ to approximately $280 \mathrm{ppt}$, which is close to the observed extreme bromine mixing ratio of about 260 ppt reported by Impey et al. (1999). A comparison of Fig. 1 and Fig. 9 shows that the addition of $\mathrm{NO}_{\mathrm{x}}$ chemistry enhances the total ozone depletion by about 2.5 days for

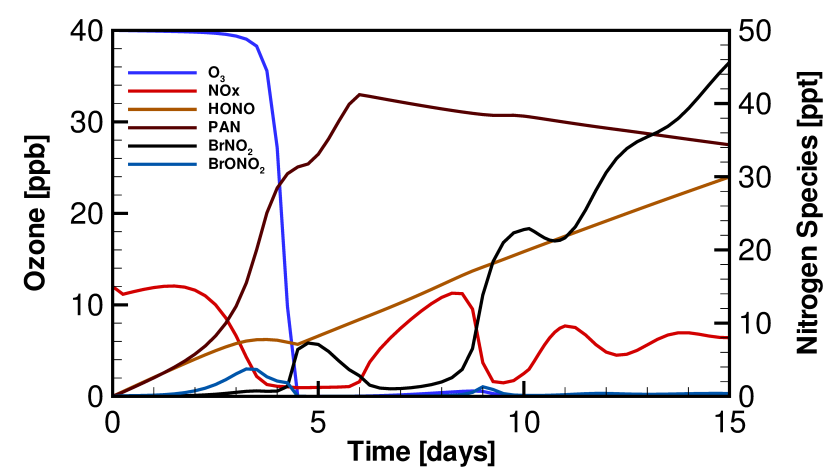

(a)

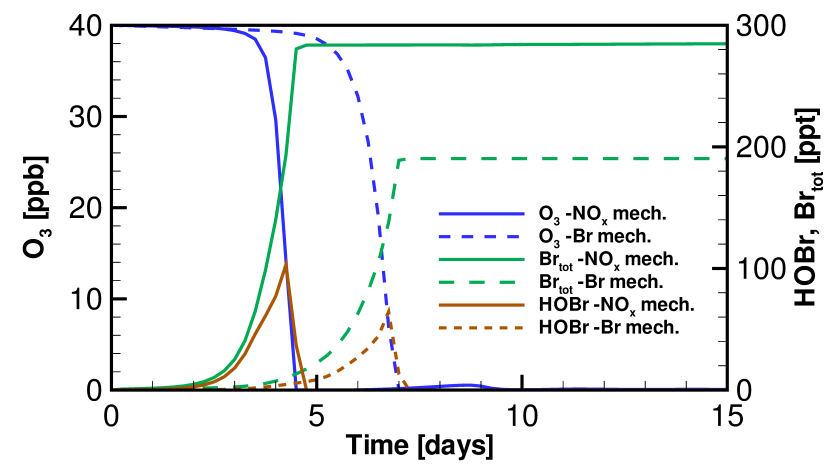

(b)

Fig. 9. Time evolution of the mixing ratios of ozone, nitrogencontaining species and bromine for a boundary layer height of $200 \mathrm{~m}$.

Table 4. List of important $\mathrm{NO}_{\mathrm{x}}$-relevant reactions (type $\mathrm{F}$ : $\mathrm{NO}_{\mathrm{x}}$ formation; type $\mathrm{D}: \mathrm{NO}_{\mathrm{x}}$ depletion).

\begin{tabular}{|c|c|c|}
\hline Reaction & No. & Type \\
\hline $\mathrm{HO}_{2}+\mathrm{NO}_{2}(+\mathrm{M}) \rightarrow \mathrm{HNO}_{4}(+\mathrm{M})$ & (R62) & $\mathrm{D}$ \\
\hline $\mathrm{HNO}_{4}(+\mathrm{M}) \rightarrow \mathrm{HO}_{2}+\mathrm{NO}_{2}(+\mathrm{M})$ & (R63) & $\mathrm{F}$ \\
\hline $\mathrm{Br}+\mathrm{NO}_{2}(+\mathrm{M}) \rightarrow \mathrm{BrNO}_{2}(+\mathrm{M})$ & (R77) & $\mathrm{D}$ \\
\hline $\mathrm{BrO}+\mathrm{NO}_{2}(+\mathrm{M}) \rightarrow \mathrm{BrONO}_{2}(+\mathrm{M})$ & (R79) & $\mathrm{D}$ \\
\hline $\mathrm{BrONO}_{2}+h v \rightarrow \mathrm{BrO}+\mathrm{NO}_{2}$ & $(\mathrm{R} 81)$ & $\mathrm{F}$ \\
\hline $\mathrm{BrNO}_{2}+h v \rightarrow \mathrm{Br}+\mathrm{NO}_{2}$ & (R82) & $\mathrm{F}$ \\
\hline $\mathrm{HNO}_{3}+h v \stackrel{\text { aerosol }}{\longrightarrow} \mathrm{NO}_{2}+\mathrm{OH}$ & $(\mathrm{R} 85)$ & $\mathrm{F}$ \\
\hline
\end{tabular}

a boundary layer height of $200 \mathrm{~m}$ compared with the results using the bromine-only mechanism.

The reactions strongly and directly affecting $\mathrm{NO}_{\mathrm{x}}$ mixing ratios are listed in Table 4, and their reaction-rate evolutions are shown in Fig. 10, which shows that the $\mathrm{NO}_{\mathrm{x}}$ mixing ratios are influenced by different reactions in different time periods. Table 5 gives a summary of the major chemical reactions affecting the mixing ratios of $\mathrm{NO}_{\mathrm{x}}$. In the early induction stage before day 3, the formation Reaction (R63) and the depletion Reaction (R62) are the most rapid $\mathrm{NO}_{\mathrm{x}}$-related reactions, most of the $\mathrm{NO}_{\mathrm{x}}$ molecules participate in this reaction pair. 


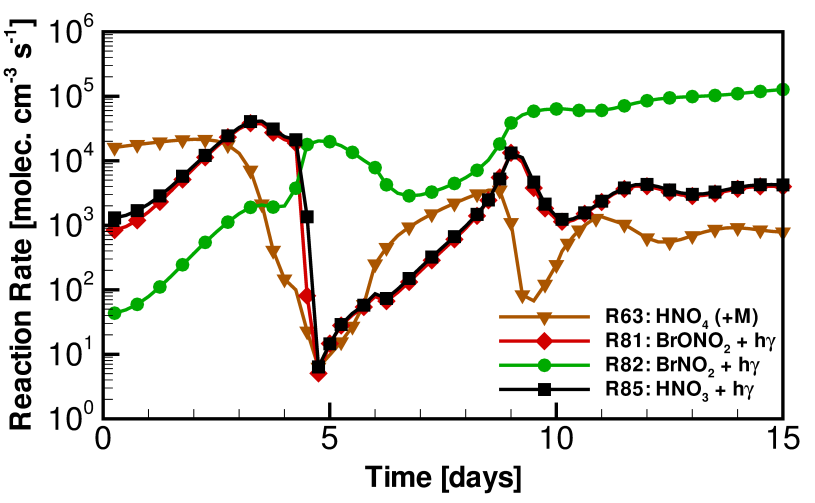

(a)

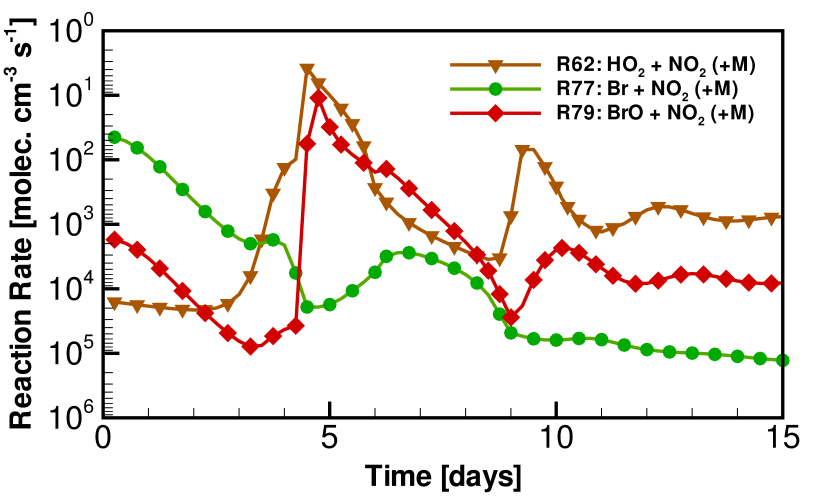

(b)

Fig. 10. Temporal evolution of $\mathrm{NO}_{\mathrm{x}}$-relevant reaction rates for a $200 \mathrm{~m}$ boundary layer height: (a) formation, (b) depletion.

Table 5. Overview of $\mathrm{NO}_{\mathrm{x}}$-relevant reactions and periods.

\begin{tabular}{lll}
\hline Reaction & No. & Period \\
\hline $\mathrm{HO}_{2}+\mathrm{NO}_{2}(+\mathrm{M}) \rightarrow \mathrm{HNO}_{4}(+\mathrm{M})$ & $(\mathrm{R} 62)$ & Induction \\
$\mathrm{HNO}_{4}(+\mathrm{M}) \rightarrow \mathrm{HO}_{2}+\mathrm{NO}_{2}(+\mathrm{M})$ & $(\mathrm{R} 63)$ & \\
\hline $\mathrm{BrO} \mathrm{NO}_{2}(+\mathrm{M}) \rightarrow \mathrm{BrONO}_{2}(+\mathrm{M})$ & $(\mathrm{R} 79)$ & \\
$\mathrm{BrONO}_{2}+h v \rightarrow \mathrm{BrO}+\mathrm{NO}_{2}$ & $(\mathrm{R} 81)$ & Depletion \\
$\mathrm{BrONO}_{2} \stackrel{\mathrm{H}}{\rightarrow} \mathrm{O}$ \\
$\mathrm{HOBr}+\mathrm{HNO}_{3}$ & $(\mathrm{R} 83, \mathrm{R} 86)$ & \\
$\mathrm{HNO}_{3} \stackrel{\text { aerosol }}{\rightarrow} \mathrm{NO}_{2}+\mathrm{OH}$ & $(\mathrm{R} 85)$ & \\
\hline $\mathrm{Br}^{\mathrm{NO}} \mathrm{NO}_{2}(+\mathrm{M}) \rightarrow \mathrm{BrNO}_{2}(+\mathrm{M})$ & $(\mathrm{R} 77)$ & After Depletion \\
$\mathrm{BrNO}_{2}+h v \rightarrow \mathrm{Br}+\mathrm{NO}_{2}$ & $(\mathrm{R} 82)$ & \\
\hline
\end{tabular}

Later, in the induction stage, most of the $\mathrm{NO}_{\mathrm{x}}$ molecules are converted to $\mathrm{BrONO}_{2}$ (see Sect. 5 of the Supplement), leading to the enhancement of the $\mathrm{BrONO}_{2}$ mixing ratio in the air. After ozone depletion has started, the Reactions (R79), (R81), and (R85) related to $\mathrm{BrONO}_{2}$ become more important. The hydrolysis Reactions (R83) and (R86) of $\mathrm{BrONO}_{2}$ constitute the most important $\mathrm{NO}_{\mathrm{x}}$ cycle during the ozone depletion. Since most of the $\mathrm{NO}_{\mathrm{x}}$ molecules are involved in this $\mathrm{BrONO}_{2}$-related cycle at this time, the reaction rates of (R62) and (R63) shortly drop. As depletion ends after 4.4 days, the

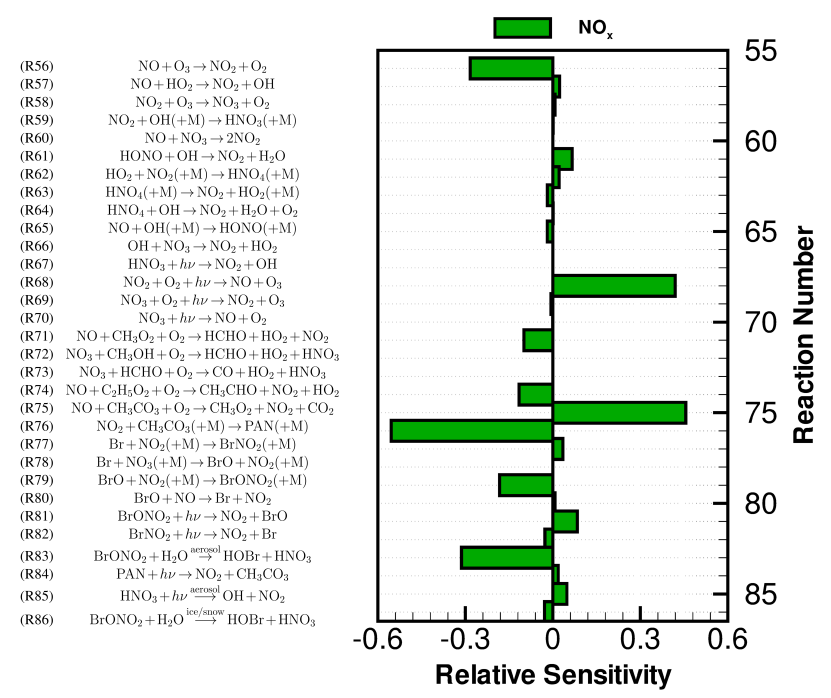

Fig. 11. Instantaneous relative sensitivities of $\mathrm{NO}_{\mathrm{x}}$ concentrations at day 4 for a boundary layer height of $200 \mathrm{~m}$.

$\mathrm{NO}_{\mathrm{x}}$-related Reaction pair (R77) and (R82) becomes prominent. The rate difference between Reactions (R77) and (R82) leads to the formation of $\mathrm{BrNO}_{2}$ at the end of the depletion event, which is also observed in the top panel in Fig. 9.

The instantaneous relative sensitivities of $\mathrm{NO}_{\mathrm{x}}$ concentrations at day 4 , which is within the ozone depletion stage (between days 3.4 and 4.4) are displayed in Fig. 11. The $\mathrm{NO}_{\mathrm{x}}$ concentrations are very sensitive to Reactions (R75) and (R76) as PAN is the major sink of nitrogen. Reaction (R75) alters the mixing ratio of $\mathrm{CH}_{3} \mathrm{CO}_{3}$, leading to a decrease in the PAN mixing ratio. PAN forms in Reaction (R76) and, therefore, the mixing ratio of $\mathrm{NO}_{\mathrm{x}}$ is reduced. Reactions (R56) and (R68), which determine the gaseous $\mathrm{NO}$ and $\mathrm{NO}_{2}$ ratio, are also crucial. It is worth noting that the hydrolysis Reaction (R83) at the aerosol surface involving $\mathrm{BrONO}_{2}$ has a large impact on the mixing ratio of $\mathrm{NO}_{\mathrm{x}}$ at this time. In Reaction (R79), moderate formation of $\mathrm{BrONO}_{2}$ occurs and Reactions (R81) and (R83) consume $\mathrm{BrONO}_{2}$, confirming the chemical reaction cycle during the ozone depletion period through the sensitivity analysis.

The instantaneous relative sensitivities of the $\mathrm{O}_{3}$ concentration for reactions related to nitrogen-containing species at day 4 are shown in Fig. 12. The sensitivities for the $\mathrm{O}_{3}$ concentration is similar to those for the $\mathrm{NO}_{\mathrm{x}}$ concentrations shown in Fig. 11. However, the sensitivities for PAN-related Reactions (R75) and (R76) are relatively lower for ozone compared to $\mathrm{NO}_{\mathrm{x}}$. For ozone, the most important $\mathrm{NO}_{\mathrm{x}}{ }^{-}$ related reaction is the hydrolysis reaction of $\mathrm{BrONO}_{2}$ at the aerosol surface (R83), since in this reaction, the $\mathrm{HOBr}$ concentration is enhanced, leading to a reduced ozone concentration. 


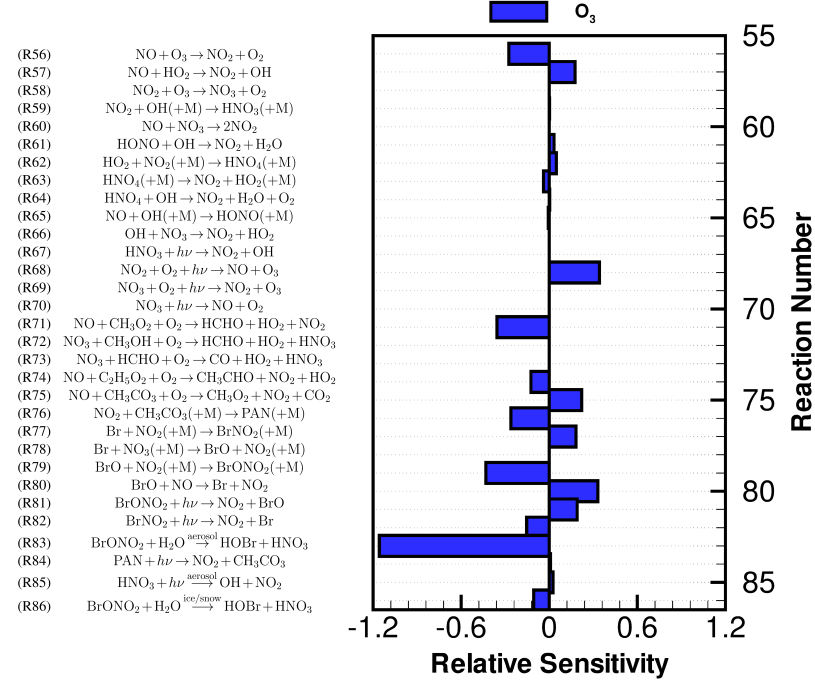

Fig. 12. Instantaneous relative sensitivities of $\mathrm{O}_{3}$ concentrations at day 4 for a boundary layer height of $200 \mathrm{~m}$.

The importance of nitrogen-related reactions versus bromine-related reactions at day 4 is shown in Figs. 12 and 13. The bromine-related reactions have a much higher sensitivity for ozone depletion compared to nitrogen-related reactions at this time. A comparison of the sensitivity coefficients of bromine-related reactions at day 6 for the bromine-only mechanism, cf. Fig. 6, and the present mechanism at day 4 shows a relatively higher sensitivity of the heterogeneous Reaction (R14) due to the increased $\mathrm{HOBr}$ concentration in the $\mathrm{NO}_{\mathrm{x}}$ mechanism (see Fig. 9); this leads to a reduced importance of Reactions (R4) and (R6) in the mechanism including $\mathrm{NO}_{\mathrm{x}}$-related reactions. However, note that the time until $\mathrm{O}_{3}$ depletion starts is considerably influenced by the presence of $\mathrm{NO}_{\mathrm{x}}$ as shown in Fig. 14, which will be discussed below.

Nitrogen-containing species are involved in both the ozone production and the destruction cycles. $\mathrm{NO}_{\mathrm{x}}$ species may help to accelerate the ozone depletion by the processes related to halogen nitrates $\left(\mathrm{XONO}_{2}\right)$. The formation of halogen nitrates and the following hydrolysis decomposition are suggested by Sander et al. (1999):

$\mathrm{XO}+\mathrm{NO}_{2} \rightarrow \mathrm{XONO}_{2}$

and

$\mathrm{XONO}_{2}+\mathrm{H}_{2} \mathrm{O} \stackrel{\mathrm{mp}}{\longrightarrow} \mathrm{HOX}+\mathrm{HNO}_{3}$,

(R83, R86)

where "mp" denotes multiphase reactions, i.e., reactions at the aerosol and at the ice/snow surface.

Halogen nitrates formed in Reaction (R79) are rather easily decomposed by hydrolysis at the sea-salt aerosol surface through Reaction (R83) or at the saline surface through Reaction (R86), producing $\mathrm{HOX}$ and $\mathrm{HNO}_{3}$, respectively. The $\mathrm{HNO}_{3}$ photolysis reaction rates at the aerosol particle surface

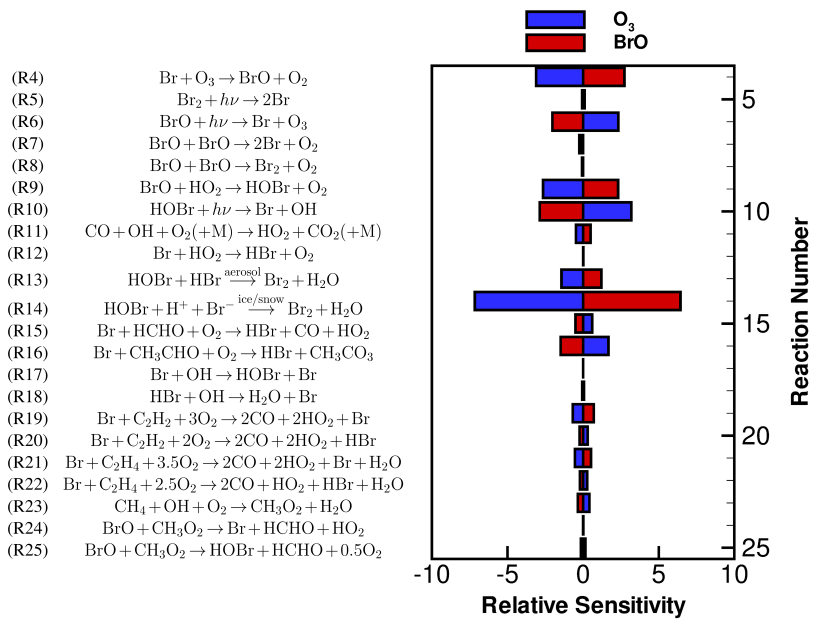

Fig. 13. Instantaneous relative sensitivities of $\mathrm{O}_{3}$ and $\mathrm{BrO}$ concentrations at day 4 for a boundary layer height of $200 \mathrm{~m}$.

is faster than in the gas phase (Finlayson-Pitts, 2009). However, this heterogeneous reaction rate remains uncertain. In the present model, it is assumed that it has the same reaction rate as the $\mathrm{BrONO}_{2}$ hydrolysis reaction with $\gamma=0.06$.

As a consequence, in the case of $\mathrm{X}=\mathrm{Br}$, the reaction cycle (I) is obtained:

$$
\begin{gathered}
\mathrm{BrO}+\mathrm{NO}_{2} \longrightarrow \mathrm{BrONO}_{2} \\
\mathrm{BrONO}_{2}+\mathrm{H}_{2} \mathrm{O} \stackrel{\mathrm{mp}}{\longrightarrow} \mathrm{HOBr}+\mathrm{HNO}_{3} \\
\mathrm{HNO}_{3}+h v \stackrel{\text { aerosol }}{\longrightarrow} \mathrm{NO}_{2}+\mathrm{OH} \\
\hline \mathrm{Net}: \quad \mathrm{BrO}+\mathrm{H}_{2} \mathrm{O}+h v \stackrel{\mathrm{mp}}{\longrightarrow} \mathrm{HOBr}+\mathrm{OH} .
\end{gathered}
$$

In cycle (I), $\mathrm{BrO}$ is sequestered into $\mathrm{BrONO}_{2}$, leading to the reduction of the amount of $\mathrm{BrO}$ and an enhancement of $\mathrm{HOBr}$ formation. The "bromine explosion" mechanism leads to an additional gaseous bromine flux released into the air, speeding up the ozone depletion process.

$\mathrm{NO}_{\mathrm{x}}$ species could also be involved in an ozone production cycle (II):

$$
\begin{aligned}
\mathrm{HO}+\mathrm{CO}+\mathrm{O}_{2} & \rightarrow \mathrm{CO}_{2}+\mathrm{HO}_{2} \\
\mathrm{HO}_{2}+\mathrm{NO} & \rightarrow \mathrm{OH}+\mathrm{NO}_{2} \\
\mathrm{NO}_{2}+h v+\mathrm{O}_{2} & \rightarrow \mathrm{NO}+\mathrm{O}_{3} \\
\hline \mathrm{Net}: \quad \mathrm{CO}+2 \mathrm{O}_{2}+h v & \rightarrow \mathrm{O}_{3}+\mathrm{CO}_{2} .
\end{aligned}
$$

Most of the ozone in the troposphere is formed through cycle (II). The rate-determining step is the conversion step from $\mathrm{NO}$ to $\mathrm{NO}_{2}$. Peroxy radicals generated from volatile organic compounds could also replace $\mathrm{HO}_{2}$ to oxidize $\mathrm{NO}$ to obtain $\mathrm{NO}_{2}$, but this occurs through a more complex chemical reaction system.

Overall, the net effect on ozone depletion through $\mathrm{NO}_{\mathrm{x}}$ species results from the balance between cycles (I) and (II). If the additional bromine flux induced by cycle (I) is 


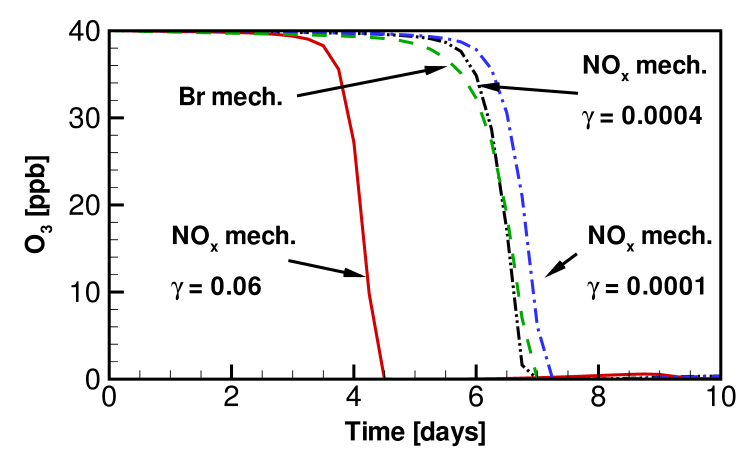

Fig. 14. Ozone depletion rates with different values of the $\mathrm{BrONO}_{2}$ hydrolysis uptake coefficient.

strong enough, the ozone depleted in cycle (I) is faster than the ozone formed through cycle (II). In this situation, $\mathrm{NO}_{\mathrm{x}}$ species accelerate the whole ozone depletion event, and vice versa.

If the heterogeneous $\mathrm{BrONO}_{2}$ hydrolysis Reactions (R83) and (R86) are negligible $(\gamma=0.0001)$, which means that only a small amount of additional HOBr molecules can be formed by nitrogen-related reactions, the presence of nitrogen-containing species will slow down ozone depletion as shown in Fig. 14. In contrast, when the value of the uptake coefficient of $\gamma=0.06$ is used in Reactions (R83) and (R86), ozone is depleted earlier than computed with the bromineonly mechanism. A critical turning value for the uptake coefficient of Reactions (R83) and (R86) can be identified as $\gamma=0.0004$. In this situation, the ozone produced by the nitrogen cycle equals the amount of ozone destroyed by the additional $\mathrm{HOBr}$ induced by nitrogen-heterogeneous Reactions (R83) and (R86), and no effect of the $\mathrm{NO}_{\mathrm{x}}$ species on the mixing ration of ozone is observed, the ozone depletion time equals the one in the bromine-only mechanism. However, as the value of the uptake coefficient for the heterogeneous $\mathrm{BrONO}_{2}$ hydrolysis reactions at the ice/snow surfaces or the aerosols is usually significantly larger than the obtained critical value in the present model, $\mathrm{NO}_{\mathrm{x}}$-related chemistry will typically enhance ozone depletion. Thus, it may be concluded that the presence of the small amount of $\mathrm{NO}_{\mathrm{x}}$ (15 ppt in the model) in the polar boundary layer may result in the acceleration of the reactive halogen release and the ozone depletion event.

The next section concerns the influence of chlorine-related chemical reactions on ozone depletion.

\subsection{Chlorine-related chemical reaction mechanism}

The mechanism including both nitrogen- and chlorinerelated species consists of 135 chemical reactions among 49 species. The mechanism and the related results are presented in the Supplement. It is found that the chemical composition of the ground surface may be important for the ozone depletion rate. Moreover, the calculated ratio of $[\mathrm{Br} / \mathrm{Cl}]$ during ozone depletion is on the order of $10^{3}$, which means that more than $99 \%$ of the ozone is consumed directly by $\mathrm{Br}$ atoms.

\section{Conclusions}

In this study, a chemical reaction mechanism for the ozone depletion and halogen release in polar spring is analyzed using a sensitivity analysis. First, a chemical kinetic mechanism including only bromine species is used, which then is extended to include $\mathrm{NO}_{\mathrm{x}}$ - and, in a second step, chlorinecontaining species. To our knowledge this is the first study to separate the influence of $\mathrm{NO}_{\mathrm{x}}$ and $\mathrm{Cl}$ species on the bromine explosion mechanism and associated ozone depletion events. When the nitrogen- and chlorine-containing species are not considered, i.e., in the bromine-only mechanism, the temporal change of mixing ratios of chemical species suggests that ozone is completely destroyed after a 5 day induction time and a $40 \mathrm{~h}$ depletion process assuming a boundary layer height of $200 \mathrm{~m}$. When the boundary layer height increases, the whole depletion process is retarded, and the average mixing ratios of bromine are reduced. The importance of the bromine-containing reactions on the ozone depletion rate is identified using a relative sensitivity analysis of the chemical reaction rates. It is shown that as the bromine loading in the air is heavily enhanced by the "bromine explosion" mechanism, the heterogeneous reactions related to $\mathrm{HOBr}$ play an important role. The physical properties such as reactive surface area offered for the heterogeneous reactions determine the heterogeneous reaction rate, thus greatly affecting the ozone depletion rates. It is found that the shortest ozone depletion period caused by local chemistry ends after 2 days.

Using the extended chemical reaction scheme including $\mathrm{NO}_{\mathrm{x}}$ chemistry, the mixing ratios of $\mathrm{NO}_{\mathrm{x}}$-related species are controlled by different chemical reactions in different time periods. During the depletion process, the most dominant $\mathrm{NO}_{\mathrm{x}}$ reaction cycle is related to $\mathrm{BrONO}_{2}$ because of the enhanced bromine concentration in the air. The importance of this chemical cycle is identified by both the study of the reaction-rate evolutions and relative sensitivity coefficients. A critical value of 0.0004 of the uptake coefficient of the $\mathrm{BrONO}_{2}$ hydrolysis reaction at the aerosol and saline surfaces is identified, beyond which the existence of $\mathrm{NO}_{\mathrm{x}}$ species accelerate the ozone depletion event, whereas for lower values, retardation occurs. 
Supplementary material related to this article is available online at http://www.atmos-chem-phys.net/14/ 3771/2014/acp-14-3771-2014-supplement.pdf.

Acknowledgements. The authors thank the German Research Foundation (DFG) for financial support through grants GU 255/6-1 and PL 193/10-1.

Edited by: W. T. Sturges

\section{References}

Adams, J. W., Holmes, N. S., and Crowley, J. N.: Uptake and reaction of $\mathrm{HOBr}$ on frozen and dry $\mathrm{NaCl} / \mathrm{NaBr}$ surfaces between 253 and 233 K, Atmos. Chem. Phys., 2, 79-91, doi:10.5194/acp2-79-2002, 2002.

Abbatt, J., Oldridge, N., Symington, A., Chukalovskiy, V., McWhinney, R. D., Sjostedt, S., and Cox, R. A.: Release of gasphase halogens by photolytic generation of $\mathrm{OH}$ in frozen halidenitrate solutions: an active halogen formation mechanism?, J. Phys. Chem. A, 114, 6527-6533, 2010.

Abbatt, J. P. D., Thomas, J. L., Abrahamsson, K., Boxe, C., Granfors, A., Jones, A. E., King, M. D., Saiz-Lopez, A., Shepson, P. B., Sodeau, J., Toohey, D. W., Toubin, C., von Glasow, R., Wren, S. N., and Yang, X.: Halogen activation via interactions with environmental ice and snow in the polar lower troposphere and other regions, Atmos. Chem. Phys., 12, 6237-6271, doi:10.5194/acp-12-6237-2012, 2012.

Aranda, A., LeBras, G., Verdet, G., and Poulet, G.: The $\mathrm{BrO}+\mathrm{CH}_{3} \mathrm{O}_{2}$ reaction: Kinetics and the role in the atmospheric budget, Geophys. Res. Lett., 24, 2745-2748, 1997.

Atkinson, R., Baulch, D. L., Cox, R. A., Crowley, J. N., Hampson, R. F., Hynes, R. G., Jenkin, M. E., Kerr, J. A., Rossi, M. J., and Troe, J.: Summary of evaluated kinetic and photochemical data for atmospheric chemistry, Web version, February 2006, http:// www.iupac-kinetic.ch.cam.ac.uk, 2006.

Barnes, I., Becker, K. H., and Overath, R. D.: Oxidation of organic sulfur compounds, in: The tropospheric chemistry of ozone in the polar regions, edited by: Niki, H. and Becker, K. H., Springer Verlag, Berlin, 1993.

Barrie, L. A., Bottenheim, J. W., Schnell, R. C., Crutzen, P. J., and Rasmussen, R. A.: Ozone destruction and photochemical reactions at polar sunrise in the lower Arctic atmosphere, Nature, 334, 138-141, 1988.

Barrie, L. A., den Hartog, G., Bottenheim, J. W., and Landsberger, S.: Anthropogenic aerosols and gases in the lower troposphere at Alert, Canada in April 1986, J. Atmos. Chem., 9, 101-127, 1989.

Beare, R. J., MacVean, M. K., Holtslag, A. A., Cuxart, J., Esau, I., Golaz, J. C., Jimenez, M. A., Khairoutdinov, M., Kosovic, B., Lewellen, D., Lund, T. S., Lundquist, J. K., McCabe, A., Moene, A. F., Noh, Y., Raasch, S., and Sullivan, P. P.: An intercomparison of large-eddy simulations of the stable boundary layer, Bound.Lay. Meteorol., 118, 247-272, 2006.

Beine, H. J., Honrath, R. E., Dominé, F., Simpson, W. R., and Fuentes, J. D.: $\mathrm{NO}_{\mathrm{x}}$ during background and ozone depletion pe- riods at Alert: Fluxes above the snow surface, J. Geophys. Res., 107, 4584, doi:10.1029/2002JD002082, 2002a.

Beine, H. J., Dominé, F., Simpson, W. R., Honrath, R. E., Sparapani, R., Zhou, X. L., and King, M.: Snow-pile and chamber experiments during the Polar Sunrise Experiment "Alert 2000": exploration of nitrogen chemistry. Atmos. Environ., 36, 2707-2719, 2002b.

Bloss, W. J., Camredon, M., Lee, J. D., Heard, D. E., Plane, J. M. C., Saiz-Lopez, A., Bauguitte, S. J.-B., Salmon, R. A., and Jones, A. E.: Coupling of $\mathrm{HO}_{\mathrm{x}}, \mathrm{NO}_{\mathrm{x}}$ and halogen chemistry in the antarctic boundary layer, Atmos. Chem. Phys., 10, 1018710209, doi:10.5194/acp-10-10187-2010, 2010.

Borken, J.: Ozonabbau durch Halogene in der arktischen Grenzschicht: Reaktionskinetische Modellrechnungen zu einem Fruehjahrsphaenomen, Diploma thesis, Universität Heidelberg, 1996.

Bottenheim, J. W., Gallant, A. C., and Brice, K. A.: Measurements of $\mathrm{NO}_{y}$ species and $\mathrm{O}_{3}$ at $82^{\circ} \mathrm{N}$ latitude, Geophys. Res. Lett., 13, 113-116, 1986.

Boudries, H. and Bottenheim, J. W.: $\mathrm{Cl}$ and $\mathrm{Br}$ atom concentrations during a surface boundary layer ozone depletion event in the Canadian High Arctic, Geophys. Res. Lett., 27, 517-520, 2000.

Boxe, C. S. and Saiz-Lopez, A.: Multiphase modeling of nitrate photochemistry in the quasi-liquid layer (QLL): implications for $\mathrm{NO}_{\mathrm{x}}$ release from the Arctic and coastal Antarctic snowpack, Atmos. Chem. Phys., 8, 4855-4864, doi:10.5194/acp-8-4855-2008, 2008.

Cao, L. and Gutheil, E.: Numerical simulation of tropospheric ozone depletion in the polar spring, Air Qual. Atmos. Health, 6, 673-686, doi:10.1007/s11869-013-0208-9, 2013.

Cao, L. and Gutheil, E.: Modeling and simulation of tropospheric ozone depletion in the polar spring, Proc. ASME 2014 4th Joint US-European Fluids Engineering Summer Meeting, 3-7 August 2014, Chicago, IL, USA, 2014.

Chen, G., Huey, L., Crawford, J., Olson, J., Hutterli, M., Sjostedt, S., Tanner, D., Dibb, J., Lefer, B., Blake, N., Davis, D., and Stohl, A.: An assessment of the polar $\mathrm{HO}_{\mathrm{x}}$ photochemical budget based on 2003 Summit Greenland field observations, Atmos. Environ., 41, 7806-7820, doi:10.1016/j.atmosenv.2007.06.014, 2007.

Courant, R., Friedrichs, K., and Lewy, H.: Über die Partiellen Differenzengleichungen der Mathematischen Physik, Math. Ann., 100, 32-74, 1928

DeMore, W. B., Sander, S. P., Goldan, D. M., Hampson, R. F., Kurylo, M. J., Howard, C. J., Ravishankara, A. R., Kolb, C. E., and Molina, M. J.: Chemical kinetics and photochemical data for use in stratospheric modeling No. 12, Jet Propulsion Laboratory, Pasadena, Publication, 97-4, 1997.

Evans, M., Jacob, D., Atlas, E. L., Cantrell, C. A., Eisele, F., Flocke, F. M., Fried, A., Mauldin, R. L., Ridley, B. A., Wert, B., Talbot, R., Blake, D., Heikes, B., Snow, J., Walega, J. G., Weinheimer, A.J., and Dibb, J.: Coupled evolution of $\mathrm{BrO}_{\mathrm{x}}-\mathrm{ClO}_{\mathrm{x}}-$ $\mathrm{HO}_{\mathrm{x}}-\mathrm{NO}_{\mathrm{x}}$ chemistry during bromine-catalyzed ozone depletion events in the arctic boundary layer, J. Geophys. Res., 108, 8368, doi:10.1029/2002JD002732, 2003.

Fan, S. M. and Jacob, D. J.: Surface ozone depletion in Arctic spring sustained by bromine reactions on aerosols, Nature, 359, 522524, 1992.

Finlayson-Pitts, B. J.: Reactions at surfaces in the atmosphere: integration of experiments and theory as necessary (but not 
necessarily sufficient) for predicting the physical chemistry of aerosols, Phys. Chem. Chem. Phys., 11, 7760-7779, 2009.

Foster, K. L., Plastridge, R. A., Bottenheim, J. W., Shepson, P. B., Finlayson-Pitts, B. J., and Spicer, C. W.: The role of $\mathrm{Br}_{2}$ and $\mathrm{BrCl}$ in surface ozone destruction at polar sunrise, Science, 291, 471-474, 2001.

Frieß, U., Hollwedel, J., König-Langlo, J., Wagner, T., and Platt, U.: Dynamics and chemistry of tropospheric bromine explosion events in the Antarctic coastal region, J. Geophys. Res., 109, D06305, doi:10.1029/2003JD004133, 2004.

Grannas, A. M., Jones, A. E., Dibb, J., Ammann, M., Anastasio, C., Beine, H. J., Bergin, M., Bottenheim, J., Boxe, C. S., Carver, G., Chen, G., Crawford, J. H., Dominé, F., Frey, M. M., Guzmán, M. I., Heard, D. E., Helmig, D., Hoffmann, M. R., Honrath, R. E., Huey, L. G., Hutterli, M., Jacobi, H. W., Klán, P., Lefer, B., McConnell, J., Plane, J., Sander, R., Savarino, J., Shepson, P. B., Simpson, W. R., Sodeau, J. R., von Glasow, R., Weller, R., Wolff, E. W., and Zhu, T.: An overview of snow photochemistry: evidence, mechanisms and impacts, Atmos. Chem. Phys., 7, 43294373, doi:10.5194/acp-7-4329-2007, 2007.

Hanson, D. R., Ravishankara, A. R., and Solomon, S.: Heterogeneous reactions in sulfuric acid aerosols: A framework for model calculations, J. Geophys. Res., 99, 3615-3629, 1994.

Hausmann, M. and Platt, U.: Spectroscopic measurement of bromine oxide and ozone in the high Arctic during Polar Sunrise Experiment 1992, J. Geophys. Res., 99, 25399-25414, 1994.

Helmig, D., Oltmans, S., Carlson, D., Lamarque, J.-F., Jones, A. E., Labuschagne, C., Anlauf, K., and Hayden, K.: A review of surface ozone in the polar regions, Atmos. Environ., 41, 51385161, doi:10.1016/j.atmosenv.2006.09.053, 2007.

Helmig, D., Boylan, P., Johnson, B., Oltmans, S., Fairall, C., Staebler, R., Weinheimer, A., Orlando, J., Knapp, D. J., Montzka, D. D., Flocke, F., Frieß, U., Sihler, H., and Shepson, P. B.: Ozone dynamics and snow-atmosphere exchanges during ozone depletion events at Barrow, Alaska, J. Geophys. Res., 117, D20303, doi:10.1029/2012JD017531, 2012.

Hönninger, G. and Platt, U.: Observations of $\mathrm{BrO}$ and its vertical distribution during surface ozone depletion at Alert, Atmos. Environ., 36, 2481-2489, 2002.

Huff, A. K. and Abbatt, J. P. D.: Gas-phase $\mathrm{Br}_{2}$ production in heterogeneous reactions of $\mathrm{Cl}_{2}, \mathrm{HOCl}$, and $\mathrm{BrCl}$ with halide-ice surfaces, J. Phys. Chem. A, 104, 7284-7293, 2000.

Huff, A. K. and Abbatt, J. P. D.: Kinetics and product yields in the heterogeneous reactions of $\mathrm{HOBr}$ with ice surfaces containing $\mathrm{NaBr}$ and $\mathrm{NaCl}$, J. Phys. Chem. A, 106, 5279-5287, 2002.

Impey, G., Mihele, C., Anlauf, K., Barrie, L., Hastie, D., and Shepson, P.: Measurements of photolyzable halogen compounds and bromine radicals during Polar Sunrise Experiment 1997, J. Atmos. Chem., 34, 21-37, 1999.

Jacobi, H.-W., Frey, M. M., Hutterli, M. A., Bales, R. C., Schrems, O., Cullen, N. J., Steffen, K., and Koehler, C.: Measurements of hydrogen peroxide and formaldehyde exchange between the atmosphere and surface snow at Summit, Greenland, Atmos. Environ., 36, 2619-2628, doi:10.1016/S1352-2310(02)00106-1, 2002.

Jobson, B. T., Niki, H., Yokouchi, Y., Bottenheim, J., Hopper, F., and Leaitch R.: Measurements of $\mathrm{C}_{2}-\mathrm{C}_{6}$ hydrocarbons during the Polar Sunrise 1992 Experiment: Evidence for $\mathrm{Cl}$ atom and $\mathrm{Br}$ atom chemistry, J. Geophys. Res., 99, 25355-25368, 1994.
Jones, A. E., Weller, R., Wolff, E. W., and Jacobi, H.-W.: Speciation and rate of photochemical $\mathrm{NO}$ and $\mathrm{NO}_{2}$ production in Antarctic snow, Geophys. Res. Lett., 27, 345-348, 2000.

Jones, A. E., Weller, R., Anderson, P. S., Jacobi, H.-W., Wolff, E. W., Schrems, O., and Miller, H.: Measurements of $\mathrm{NO}_{\mathrm{x}}$ emissions from the Antarctic snowpack, Geophys. Res. Lett., 28, 1499-1502, 2001.

Jones, A. E., Anderson, P. S., Wolff, E. W., Turner, J., Rankin, A. M., and Colwell, S. R.: A role for newly forming sea ice in springtime polar tropospheric ozone loss? Observational evidence from Halley station, Antarctica, J. Geophys. Res., 111, D08306, doi:10.1029/2005JD006566, 2006.

Jones, A. E., Anderson, P. S., Begoin, M., Brough, N., Hutterli, M. A., Marshall, G. J., Richter, A., Roscoe, H. K., and Wolff, E. W.: $\mathrm{BrO}$, blizzards, and drivers of polar tropospheric ozone depletion events, Atmos. Chem. Phys., 9, 4639-4652, doi:10.5194/acp-94639-2009, 2009.

Jones, A. E., Anderson, P. S., Wolff, E. W., Roscoe, H. K., Marshall, G. J., Richter, A., Brough, N., and Colwell, S. R.: Vertical structure of Antarctic tropospheric ozone depletion events: characteristics and broader implications, Atmos. Chem. Phys., 10, 7775-7794, doi:10.5194/acp-10-7775-2010, 2010.

König, G.: Roughness length of an Antarctic ice shelf, Polarforschung, 55, 27-32, 1985.

Kreher, K., Johnston, P. V., Wood, S. W., Nardi, B., and Platt, U.: Ground-based measurements of tropospheric and stratospheric $\mathrm{BrO}$ at Arrival Heights, Antarctica, Geophys. Res. Lett., 24, 3021-3024, 1997.

Langendörfer, U., Lehrer, E., Wagenbach, D., and Platt, U.: Observation of filterable bromine variabilities during Arctic tropospheric ozone depletion events in high time resolution, J. Atmos. Chem., 34, 39-54, 1999.

Lehrer, E., Hönninger, G., and Platt, U.: A one dimensional model study of the mechanism of halogen liberation and vertical transport in the polar troposphere, Atmos. Chem. Phys., 4, 2427 2440, doi:10.5194/acp-4-2427-2004, 2004.

Liao, J., Huey, L. G., Tanner, D. J., Brough, N., Brooks, S., Dibb, J. E., Stutz, J., Thomas, J. L., Lefer, B., Haman, C., and Gorham, K.: Observations of hydroxyl and peroxy radicals and the impact of BrO at Summit, Greenland in 2007 and 2008, Atmos. Chem. Phys., 11, 8577-8591, doi:10.5194/acp-11-8577-2011, 2011.

Liao, J., Huey, L. G., Tanner, D. J., Flocke, F. M., Orlando, J. J., Neuman, J. A., Nowak, J. B., Weinheimer, A. J., Hall, S. R., Smith, J. N., Fried, A., Staebler, R. M., Wang, Y., Koo, J.-H., Cantrell, C. A., Weibring, P., Walega, J., Knapp, D. J., Shepson, P. B., and Stephens, C. R.: Observed and modeled inorganic bromine ( $\mathrm{HOBr}, \mathrm{BrO}$, and $\left.\mathrm{Br}_{2}\right)$ speciation at Barrow, AK in spring 2009, J. Geophys. Res., 117, D00R16, doi:10.1029/2011JD016641, 2012.

Michalowski, B. A., Francisco, J. S., Li, S. M., Barrie, L. A., Bottenheim, J. W., and Shepson, P. B.: A computer model study of multiphase chemistry in the Arctic boundary layer during polar sunrise, J. Geophys. Res., 105, 15131-15145, 2000.

Morin, S., Marion, G. M., von Glasow, R., Voisin, D., Bouchez, J., and Savarino, J.: Precipitation of salts in freezing seawater and ozone depletion events: a status report, Atmos. Chem. Phys., 8, 7317-7324, doi:10.5194/acp-8-7317-2008, 2008.

Oldridge, N. W. and Abbatt, J.: Formation of gas-phase bromine from interaction of ozone with frozen and liquid $\mathrm{NaCl} / \mathrm{NaBr}$ 
solutions: quantitative separation of surficial chemistry from bulk-phase reaction, J. Phys. Chem. A, 115, 2590-2598, 2011.

Oltmans, S. J.: Surface ozone measurements in clean air, J. Geophys. Res., 86, 1174-1180, 1981.

Oltmans, S. J., Schnell, R. C., Sheridan, P. J., Peterson, R. E., Li, S. M., Winchester, J. W., Tans, P. P., Sturges, W. T., Kahl, J. D., and Barrie, L. A.: Seasonal surface ozone and filterable bromine relationship in the high Arctic, Atmos. Environ., 23, 2431-2441, 1989.

Oltmans, S. J., Johnson, B. J., and Harris, J. M.: Springtime boundary layer ozone depletion at Barrow, Alaska: Meteorological influence, year-to-year variation, and long-term change, J. Geophys. Res., 117, D00R18, doi:10.1029/2011JD016889, 2012.

Perner, D., Arnold, T., Crowley, J., Klüpfel, T., Martinez, M., and Seuwen, R.: The measurements of active chlorine in the atmosphere by chemical amplification, J. Atmos. Chem., 34, 9-20, 1999.

Piot, M. and von Glasow, R.: The potential importance of frost flowers, recycling on snow, and open leads for ozone depletion events, Atmos. Chem. Phys., 8, 2437-2467, doi:10.5194/acp-82437-2008, 2008.

Piot, M. and von Glasow, R.: Modelling the multiphase near-surface chemistry related to ozone depletions in polar spring, J. Atmos. Chem., 64, 77-105, 2009.

Platt, U. and Hönninger, G.: The role of halogen species in the troposphere, Chemosphere, 52, 325-338, 2003.

Platt, U. and Janssen, C.: Observation and role of the free radicals $\mathrm{NO}_{3}, \mathrm{ClO}, \mathrm{BrO}$, and $\mathrm{IO}$ in the troposphere, Faraday Discuss., 100, 175-198, 1995.

Platt, U. and Lehrer, E.: Arctic Tropospheric Ozone Chemistry, ARCTOC, Final Report of the EU-Project EV5V-CT93-0318, Heidelberg, 1997.

Platt, U. and Moortgat, G. K.: Heterogeneous and homogeneous chemistry of reactive halogen compounds in the lower troposphere, J. Atmos. Chem., 34, 1-8, 1999.

Ramacher, B., Rudolph, J., and Koppmann, R.: Hydrocarbon measurements during tropospheric ozone depletion events: Evidence for halogen atom chemistry, J. Geophys. Res., 104, 3633-3653, 1999.

Rankin, A. M., Wolff, E. W., and Martin, S.: Frost flowers: Implications for tropospheric chemistry and ice core interpretation, J. Geophys. Res., 107, 4683, doi:10.1029/2002JD002492, 2002.

Ridley, B. A. and Orlando, J. J.: Active nitrogen in surface ozone depletion events at alert during spring 1998, J. Atmos. Chem., 44, 1-22, 2003.

Röth, E. P.: A fast algorithm to calculate the photon flux in optically dense media for use in photochemical models, Ber. Bunsenges Phys. Chem., 96, 417-420, 1992.

Röth, E. P.: Description of the anisotropic radiation transfer model ART to determine photodissociation coefficients, report, Inst. für Stratospharische Chem., Forsch. Julich, Julich, Germany, 2002.

Sander, R. and Crutzen, P. J.: Model study indicating halogen activation and ozone destruction in polluted air masses transported to the sea, J. Geophys. Res., 101, 9121-9138, 1996.

Sander, R. and Morin, S.: Introducing the bromide/ alkalinity ratio for a follow-up discussion on "Precipitation of salts in freezing seawater and ozone depletion events: a status report", by Morin et al., published in Atmos. Chem. Phys., 8, 7317-7324, 2008,
Atmos. Chem. Phys., 10, 7655-7658, doi:10.5194/acp-10-76552010, 2010.

Sander, R., Vogt, R., Harris, G. W., and Crutzen, P. J.: Modelling the chemistry of ozone, halogen compounds, and hydrocarbons in the arctic troposphere during spring, Tellus B, 49, 522-532,1997.

Sander, R., Rudich, Y., von Glasow, R., and Crutzen, P. J.: The role of $\mathrm{BrNO}_{3}$ in marine tropospheric chemistry: A model study, Geophys. Res. Lett., 26, 2857-2860, 1999.

Sander, R., Burrows, J., and Kaleschke, L.: Carbonate precipitation in brine - a potential trigger for tropospheric ozone depletion events, Atmos. Chem. Phys., 6, 4653-4658, doi:10.5194/acp-64653-2006, 2006.

Schwartz, S. E.: Mass-transport considerations pertinent to aqueous-phase reactions of gases in liquid-water clouds, in: Chemistry of Multiphase Atmospheric Systems, edited by: Jaeschke, W., Springer, Heidelberg, 415-471, 1986.

Seinfeld, J. H. and Pandis S. N.: Atmospheric chemistry and physics: from air pollution to climate change, John Wiley and Sons, New York, 1988.

Simpson, W. R., von Glasow, R., Riedel, K., Anderson, P., Ariya, P., Bottenheim, J., Burrows, J., Carpenter, L. J., Frieß, U., Goodsite, M. E., Heard, D., Hutterli, M., Jacobi, H.-W., Kaleschke, L., Neff, B., Plane, J., Platt, U., Richter, A., Roscoe, H., Sander, R., Shepson, P., Sodeau, J., Steffen, A., Wagner, T., and Wolff, E.: Halogens and their role in polar boundary-layer ozone depletion, Atmos. Chem. Phys., 7, 4375-4418, doi:10.5194/acp-74375-2007, 2007.

Solberg, S., Schmidtbauer, N., Semb, A., Stordal, F., and Hov, Ø.: Boundary-layer ozone depletion as seen in the Norwegian Arctic in spring, J. Atmos. Chem., 23, 301-332, 1996.

Spicer, C. W., Plastridge, R. A., Foster, K. L., Finlayson-Pitts, B. J., Bottenheim, J. W., Grannas, A. M., and Shepson, P. B.: Molecular halogens before and during ozone depletion events in the Arctic at polar sunrise: concentration and sources, Atmos. Environ., 36, 2721-2731, 2002.

Staebler, R., Toom-Sauntry, D., Barrie, L., Langendörfer, U., Lehrer, E., Li, S.-M., and Clark, H. D.: Physical and chemical characteristics of aerosols at Spitsbergen in the spring of 1996, J. Geophys. Res., 104, 5515-5529, 1999.

Stephens, C., Shepson, P. B., Steffen, A., Bottenheim, J. W., Liao, J., Huey, L. G., Apel, E., Weinheimer, A., Hall, S. R., Cantrell, C., Sive, B. C., Knapp, D. J., Montzka, D. D., and Hornbrook, R. S.: The relative importance of Chlorine and Bromine radicals in the oxidation of atmospheric Mercury at Barrow, AK, J. Geophys. Res., 117, D00R11, doi:10.1029/2011JD016649, 2012.

Stull, R. B.: An introduction to boundary layer meteorology, Kluwer Academic Publishers, Dordrecht, the Netherlands, 666 pp., 1988.

Tang, T. and McConnell, J. C., Autocatalytic release of bromine from Arctic snow pack during polar sunrise, Geophys. Res. Lett., 23, 2633-2636, 1996.

Thomas, J. L., Stutz, J., Lefer, B., Huey, L. G., Toyota, K., Dibb, J. E., and von Glasow, R.: Modeling chemistry in and above snow at Summit, Greenland - Part 1: Model description and results, Atmos. Chem. Phys., 11, 4899-4914, doi:10.5194/acp-11-48992011, 2011.

Thomas, J. L., Dibb, J. E., Huey, L. G., Liao, J., Tanner, D., Lefer, B., von Glasow, R., and Stutz, J.: Modeling chemistry in and above snow at Summit, Greenland - Part 2: Impact of snowpack chemistry on the oxidation capacity of the boundary layer, 
Atmos. Chem. Phys., 12, 6537-6554, doi:10.5194/acp-12-65372012, 2012.

Toyota, K., McConnell, J. C., Lupu, A., Neary, L., McLinden, C. A., Richter, A., Kwok, R., Semeniuk, K., Kaminski, J. W., Gong, S.-L., Jarosz, J., Chipperfield, M. P., and Sioris, C. E.: Analysis of reactive bromine production and ozone depletion in the Arctic boundary layer using 3-D simulations with GEM-AQ: inference from synoptic-scale patterns, Atmos. Chem. Phys., 11, 3949-3979, doi:10.5194/acp-11-3949-2011, 2011.

Toyota, K., McConnell, J. C., Staebler, R. M., and Dastoor, A. P.: Air-snowpack exchange of bromine, ozone and mercury in the springtime Arctic simulated by the 1-D model PHANTAS - Part 1: In-snow bromine activation and its impact on ozone, Atmos. Chem. Phys. Discuss., 13, 20341-20418, doi:10.5194/acpd-1320341-2013, 2013.

Tuckermann, M., Ackermann, R., Gölz, C., Lorenzen-Schmidt, H., Senne, T., Stutz, J., Trost, B., Unold, W., and Platt, U.: DOASobservation of halogen radical-catalyzed arctic boundary layer ozone destruction during the ARCTOC-campaigns 1995 and 1996 in Ny-Ålesund, Spitsbergen, Tellus B, 49, 533-555, 1997.

Turanyi, T.: KINAL: A program package for kinetic analysis of reaction mechanisms, Computers and Chemistry, 14, 253-254, 1990.

Valko, P. and Vajda, S.: An extended ODE solver for sensitivity calculations, Computers and Chemistry, 8, 255-271, 1984.

von Glasow, R. and Crutzen, P. J.: Model study of multiphase DMS oxidation with a focus on halogens, Atmos. Chem. Phys., 4, 589608, doi:10.5194/acp-4-589-2004, 2004.

von Glasow, R., Sander, R., Bott, A., and Crutzen, P. J.: Modeling halogen chemistry in the marine boundary layer 1. Cloud-free MBL, J. Geophys. Res., 107, 4341, doi:10.1029/2001JD000942, 2002a.

von Glasow, R., Sander, R., Bott, A., and Crutzen, P. J.: Modeling halogen chemistry in the marine boundary layer 2. Interactions with sulfur and the cloud-covered MBL, J. Geophys. Res., 107, 4323, doi:10.1029/2001JD000943, 2002 b.
Wagner, T., Ibrahim, O., Sinreich, R., Frieß, U., von Glasow, R., and Platt, U.: Enhanced tropospheric BrO over Antarctic sea ice in mid winter observed by MAX-DOAS on board the research vessel Polarstern, Atmos. Chem. Phys., 7, 3129-3142, doi:10.5194/acp-7-3129-2007, 2007.

Wayne, R. P., Poulet, G., Biggs, P., Burrows, J. P., Cox, R. A., Crutzen, P. J., Hayman, G. D., Jenkin, M. E., Le Bras, G., Moortgat, G. K., Platt, U., and Schindler, R. N.: Halogen oxides: Radicals, sources and reservoirs in the laboratory and in the atmosphere, Atmos. Environ., 29, 2677-2884, 1995.

Wennberg, P. O.: Atmospheric chemistry: Bromine explosion, Nature, 397, 299-301, 1999.

Yang, X., Cox, R. A., Warwick, N. J., Pyle, J. A., Carver, G. D., O'Connor, F. M., and Savage, N. H.: Tropospheric bromine chemistry and its impacts on ozone: a model study, J. Geophys. Res., 110, D23311, doi:10.1029/2005JD006244, 2005.

Yang, X., Pyle, J. A., and Cox, R. A.: Sea salt aerosol production and bromine release: Role of snow on sea ice, Geophys. Res. Lett., 35, L16815, doi:10.1029/2008GL034536, 2008.

Yang, X., Pyle, J. A., Cox, R. A., Theys, N., and Van Roozendael, M.: Snow-sourced bromine and its implications for polar tropospheric ozone, Atmos. Chem. Phys., 10, 7763-7773, doi:10.5194/acp-10-7763-2010, 2010.

Zeng, T., Wang, Y., Chance, K., Browell, E. V., Ridley, B. A., and Atlas, E. L.: Widespread persistent near-surface ozone depletion at northern high latitudes in spring, Geophys. Res. Lett., 30, 2298, doi:10.1029/2003GL018587, 2003.

Zeng, T., Wang, Y., Chance, K., Blake, N., Blake, D., and Ridley, B.: Halogen-driven low-altitude $\mathrm{O}_{3}$ and hydrocarbon losses in spring at northern high latitudes, J. Geophys. Res., 111, D17313, doi:10.1029/2005JD006706, 2006.

Zhao, T. L., Gong, S. L., Bottenheim, J. W., McConnell, J. C., Sander, R., Kaleschke, L., Richter, A., Kerkweg, A., Toyota, K., and Barrie, L. A.: A three-dimensional model study on the production of $\mathrm{BrO}$ and Arctic boundary layer ozone depletion, J. Geophys. Res., 113, D24304, doi:10.1029/2008JD010631, 2008. 